\title{
The Predictive Value of Bank Fair Values
}

\author{
Dimu Ehalaiye* \\ School of Accountancy, \\ Massey University, \\ Palmerston North, New Zealand. \\ o.ehalaiye@massey.ac.nz \\ Mark Tippett \\ Business School, \\ University of Newcastle, \\ New South Wales, Australia. \\ Business School, \\ University of Sydney, \\ New South Wales, Australia. \\ M.Tippett@1boro.ac.uk
}

\author{
Tony van Zijl \\ School of Accounting and Commercial Law, \\ Victoria University of Wellington, \\ Wellington, New Zealand. \\ tony.vanzijl@vuw.ac.nz
}

Accepted manuscript. Please cite this article as:

Ehalaiye, D., Tippett, M., \& van Zijl, T. (2017). The predictive value of bank fair values. Pacific-Basin Finance Journal, 41(February), 111-127. doi: $10.1016 /$ j.pacfin.2016.10.008

\footnotetext{
* Corresponding author.
} 


\title{
The Predictive Value of Bank Fair Values
}

\begin{abstract}
Fair value - value in an orderly market exchange - has been shown to have greater value relevance than historical cost. However, there is limited literature on the predictive ability of fair value. Our study contributes to this emerging area of research by examining the predictive ability of the SFAS 107 fair value disclosures by U.S. banks for future performance as measured by operating cash flows and earnings over a three-year time horizon. Furthermore, we provide evidence on the influence of the 2007/2008 Global Financial Crisis (GFC) on the relationships between bank fair values and future performance, thereby showing whether market illiquidity affected the underlying relationships. We also test for the impact of bank characteristics - size, capital adequacy and growth prospects - on predictive ability. Our findings suggest that fair values have predictive ability for both the cash flow and earnings measures of performance and that the GFC did not have an adverse impact on the predictive ability of bank fair values. However, we find that the predictive ability of fair value is strongest for operating cash flows. The study supports the relevance of fair value, as indicated by predictive ability for performance, and thus makes an important contribution to the fair value accounting and accounting standard-setting literature.
\end{abstract}

Keywords: Fair Value Accounting, Predictive Value, Operating Earnings, Operating Cash flows.

JEL Classification: G21 M41 M48 


\section{Introduction}

Fair value estimates represent the present value of the expected future cash flows associated with an asset [or liability] (Barth, 2000:19; Ryan, 2008:12). A series of studies have established the importance of fair value by showing its greater relevance to investors based on the relationship of fair value with the share price or market value of a firm, especially when fair values are compared with the traditional historical/amortized cost concepts of accounting for net assets (Barth, 1994; Barth, Beaver, and Landsman, 1996; Eccher, Ramesh, and Thiagarajan, 1996; Song, Thomas and Han, 2010). However, unlike the capital markets valuerelevance line of research, assessment of the effects of fair values in terms of the predictive value for future cash flows and earnings has not been extensively addressed in the literature ${ }^{1}$. Here, the Financial Accounting Standards Board (FASB, 2010:17) has emphasized that predictive value is an important and desirable attribute in accounting for an asset ${ }^{2}$. In particular, the FASB has expressed the view that the asset values shown in financial statements should communicate information about the potential future financial performance of firms. Whilst Ball (2008), Barth (2006) and Tweedie (2008) amongst others have argued that predictability is an inherent characteristic of fair value measurement, others contend that fair values are so nebulous and unreliable - especially when markets are illiquid - as to have no predictive value whatsoever (Leone 2008). In this paper we address this debate by

\footnotetext{
${ }^{1}$ Notable studies in this emerging area include Aboody, Barth and Kasznik (1999) who examined the effects of upward revaluations of fixed assets of U.K. non-financial firms on their future operating performance; Evans, Hodder and Hopkins (2014) who studied the relationship between the accumulated fair value adjustments for investment securities of a sample of U.S. commercial banks and the realized income from the investment securities in the following period; and Bratten et al. (2016) who found that fair value adjustments included in other comprehensive income of banks can predict banks' future earnings, especially net unrealized gains and losses on available-for-sale securities.

${ }^{2}$ Financial information has predictive value if it can be used as an input to processes employed by users to predict future outcomes. For example, revenue information for the current year should be useful in predicting revenues in future years. However, predictive value in the context of the FASB Conceptual Framework is not the same as predictability and persistence as used in statistics which measures the accuracy with which it is possible to forecast future numbers (such as analyzing forecast errors) in a series (FASB, 2010:25).
} 
summarizing empirical evidence relating to the predictive ability of fair values during both normal and abnormal (that is, Global Financial Crisis) market conditions.

As noted by Bernard (1993), empirical work based on the relationship between stock prices and accounting variables is invariably subject to a correlated omitted variables problem because of the potentially large number of accounting (and other control) variables that simultaneously affect stock prices. Bernard (1993) suggests that one can address this problem by ignoring stock prices and instead focusing directly on the relationships which exist amongst the accounting variables of interest. Our empirical analysis is based on this suggestion of Bernard (1993) in that it assesses the predictive ability of fair values by examining the relationship between current net fair values and future operating cash flows and earnings. ${ }^{3}$

During the Global Financial Crisis (GFC), objections to the application of fair value accounting by financial institutions, especially by banks and their lobby groups, increased significantly (Laux and Leuz 2009; Ryan, 2008:18). ${ }^{4}$ The interesting aspect is that during the boom era (pre-the $1^{\text {st }}$ quarter 2007) financial institutions did not lament the use of fair values. Robert Herz, then chairman of the FASB, stated that in 2006 a group of financial institutions called on the FASB to extend the application of fair value measurement to areas of the balance sheet that had been excluded by SFAS 107: Disclosures about Fair Value of Financial Instruments (Katz, 2008a) ${ }^{5}$. However, during the financial crisis the position changed from

\footnotetext{
${ }^{3}$ Studies such as Evans, et al. (2014) and Magnan, Menini and Parbonetti (2015) have also adopted this approach.

${ }^{4}$ In 2008 a significant number of discussion articles relating to fair value accounting issues were uploaded onto the CFO.com website. Indeed, fair value accounting was the most popular topic for discussion on the CFO.com website in 2008. Many of the articles represented negative views by bankers about the use of fair value accounting during the economic downturn.

${ }^{5}$ SFAS 107 became effective for financial statements issued for fiscal years ending after 15 December, 1992.
} 
extolling the virtues of fair value measurement to the many calls for its suspension. Concerns increased, especially with the application of SFAS 157: Fair Value Measurements, with regard to issues about illiquidity, prudential/regulatory guidelines compliance and references to forced selling of assets to raise capital, which has been argued as further depressing asset prices during the GFC (Ryan, 2008; Plantin, Sapra and Shin, 2008) ${ }^{6}$.

Although the financial crisis had a significant impact on financial institutions, the reality is that the primary attention of FASB standards is on investors and hence, it is important to know whether fair values do have predictive value. Advocates of fair value accounting have responded to the bankers' protests by suggesting that fair values provided a clear warning that markets were taking a downward turn, thus hinting at the predictive qualities of bank fair values (Ball, 2008; Tweedie, 2008). McGregor (2012), a former International Accounting Standards Board (IASB) board member, noted that in the wake of the GFC a number of commentators had observed that the effect of the GFC could have been much worse if accounting standards had not forced companies to recognize the effects of falling prices in their financial statements sooner than might otherwise have been the case. This affirms the importance of fair value accounting as it is the principal accounting measurement basis that recognizes falling prices in financial statements.

The research reported in this paper is motivated by this background debate and seeks answers to the following specific research questions:

1. Do the net fair values summarized in bank financial statements predict future financial performance as measured by operating cash flows and earnings over a three-year future time horizon?

\footnotetext{
${ }^{6}$ SFAS 157 became effective for financial statements issued for fiscal years ending after 15 November, 2007.
} 
2. Do bank net fair values have predictive value in relation to banks' future financial performance during the 2007/2008 global financial crisis? ${ }^{7}$

The second question is motivated by the previously noted and often strongly held view that SFAS 157 contributed to the forced selling of assets at artificially discounted prices during the GFC as epitomized by the following question posed of Robert Herz, then FASB chairman (Katz, 2008b):

"Did SFAS 157 correctly sound an early alarm on the financial crisis-or did it make a bad situation worse?"

Here we would note that there have been a number of studies that have addressed the second part of the above question relating to procyclicality (e.g. Badertscher, Burks, and Easton, 2011; Laux, 2012; Shaffer, 2010). In contrast, only a few studies have attempted to address the first part of the question dealing with the predictive abilities of fair values?

We address our research questions by building on the conceptual ideal of decision-usefulness which underpins the fair value paradigm and the efficient market hypothesis and which gives credence to the fair value (based on exit prices) reporting approach espoused by the FASB and IASB. This leads on to the theoretical framework which underscores the relationship between the market value of bank equity and the fair values of its assets and liabilities as summarized in its published financial statements. Agency theory is then used to explain why managers have incentives to over (or under) estimate reported fair values and how this could lead to systematic biases in the fair values summarized in banks' published financial

\footnotetext{
${ }^{7}$ Ehalaiye, Tippett and van Zijl (2016) examine this research question from the perspective of the levels classified fair values disclosed quarterly by banks based on SFAS 157 that was implemented from the first quarter of 2008, coinciding with the global financial crises period. This study on the other hand looks at the predictive value of bank fair values based on SFAS 107 requirements using annual data from 1995-2011.
} 
statements. We develop an equity valuation model based on the future cash flows a firm expects to generate and this is used to explain how future cash flows are linked to the fair values summarized in a firm's financial statements for its assets and liabilities. Following on from this, we develop hypotheses connecting the fair values summarized in a firm's published financial statements, with its future cash flows and its future earnings. Specifically, the hypotheses we develop address the question of whether there is a significant relationship between the on-balance sheet financial instrument fair values reported by banks and their future cash flows and earnings.

Our empirical analysis is focused on a sample of U.S. banks that met the requirements to disclose the fair values of their on-balance sheet financial instruments, in accordance with SFAS 107 during the period from 1995 until 2011. We find compelling empirical evidence that there is a predictive relationship between bank fair values and the operating cash flows and operating earnings of the affected banks over a three-year future time horizon. Here the predictive relationship between net asset bank fair values and operating cash flows is significantly stronger than the predictive relationship between net asset bank fair values and operating earnings. We also find that characteristics, such as bank size, capital adequacy and a bank's growth prospects impact differently on the relationship between net asset fair values and future operating cash flows and earnings. In particular fair values are a more reliable index of future cash flows for smaller as against larger banks. Moreover, higher levels of capital adequacy (and hence, lower levels of financial risk) lead to a more robust relationship between fair values and future operating cash flows. In contrast, a bank's growth prospects appear to have little impact on the relationship between the fair values summarized in its financial statements and its future operating cash flows and operating earnings. 
Our empirical results provide compelling evidence that net asset fair values have predictive value as claimed by Ball (2008); Barth (2006) and Tweedie (2008). The findings are consistent with the FASB's view that the asset values shown in firm financial statements should communicate information about the future financial performance of the firms (FASB 2010:17). Our findings also show that the GFC and the market illiquidity associated with it did not have a significant adverse impact on the predictive capacity of bank fair values.

Our study is the first in the literature in at least three ways. First, the study provides direct empirical evidence about the relationship between U.S. bank fair value disclosures and banks' future performance as measured by their operating cash flows and operating earnings over a three-period future time horizon ${ }^{8}$. Second, the study evaluates the effects of the GFC years of 2007 and 2008 on the stability of the underlying empirical relationships. Third, the study contributes to the literature methodologically, by introducing the inverse hyperbolic sine transformation to address the issue of heteroscedasticity. This transformation addresses issues of heteroscedasticity without biasing parameter estimates and inducing spurious correlation as would be the case if we had followed the conventional procedure of standardizing both the independent and dependent variables in our regression models by the book value of assets or a similar deflation variable (Pearson, 1897; Laubscher, 1961; Sokal and Rohlf, 1981:859, Ohlson, 2015). In documenting the relationship between fair values and future operating cash flows and earnings of banks our study contributes to the pre-existing literature on the relevance of fair values to investors and other stakeholders (especially during financial crises) and therefore will be of assistance to policy framers and regulators such as the Securities and

\footnotetext{
${ }^{8}$ Evans, et al. (2014) have also studied this relationship but focused on only one asset class - investment securities - and considered the impact of fair value disclosure on realized income in just one subsequent period. Our study examines the impact of net fair value disclosures for ten asset and six liability classes on future cash flows and earnings over three subsequent periods and is thus more robust and broader in scope.
} 
Exchange Commission (SEC), the FASB and the IASB as they examine the accounting issues which arise from the reporting of fair values in corporate financial statements.

The remainder of the paper is organized as follows: In section 2, we discuss the theoretical framework and develop the hypotheses on which our empirical analysis is based. In section 3 , we outline our research methodology and regression models. In section 4, we report our empirical results whilst in Section 5 we summarize the results and present our conclusions.

\section{Theoretical framework and hypothesis development}

\subsubsection{Conceptual guide, Agency theory and Fair value estimation}

The conceptual frameworks developed by both the FASB and the IASB are based on the principle of decision-usefulness (FASB, 2010:1; IASB, 2010:9). This is highlighted in the primary quality for accounting information: it must be useful for decision-making and for it to be useful, such information must be relevant. Hitz (2007) notes how standard setters have taken an economic view of measurement and this favors the fair value paradigm that utilizes the market price as the relevant metric. The reason that market price is assumed to be relevant is because of the efficient markets hypothesis (Fama 1970, 1991) which says that the market price aggregates in an efficient and unbiased manner the expectations of investors in the market concerning the cash flow patterns of the assets and liabilities appearing in a firm's financial statements (Hitz, 2007). Thus, under (the semi-strong interpretation of) the efficient markets hypothesis, the market price of a firm's equity will reflect the fair values of its assets and liabilities as summarized in its published financial statements. This idea has had a profound impact on the theoretical framework which informs the value relevance models that have been employed by researchers and others to assess the impact of fair value disclosures 
(Eccher, et al., 1996; Barth, 1991; Barth, 1994). The basis for this approach is that the present value of the future operating cash flows a firm is expected to generate is represented by the net aggregate market value of its individual assets and liabilities.

This approach is also emphasized in the conceptual definition of fair value given by both the IASB and the FASB as the "exit price" of a firm's individual asset and liability classifications which in turn, should equate to a firm's market price. The evidence for this is extensive in the U.S. banking industry as banks have been required to disclose estimates of the fair values of their financial assets and liabilities in accordance with the requirements of SFAS 107 since 1992. The fair value estimates are in particular expected to utilize the market values of the individual assets and liabilities as inputs in the estimation process as much as possible in order to abide by the spirit of the exit price definition of fair values. However, some of these estimates are subject to managerial discretion and measurement error. This in turn means that the moral hazard of managerial incentives could be manifested in the fair value estimation process.

Jensen and Meckling (1976) describe the agency relationship as a contract where the shareholders (the principal) engage management (the agent) to manage the firm's operations in a way that is consistent with stockholders' expectations. A major difficulty that can arise from this agency relationship is the problem of information asymmetry between managers and shareholders, as managers will in general possess superior information about the current and expected future performance of the firm when compared to stockholders. This information asymmetry leads to a situation where the managers are incentivized to project a favorable picture of the firm's performance in order to maximize the personal benefits they expect to receive from the firm. It is highly probable that these incentives will lead to biases in the information summarized in a firm's published financial statements. Evidence for this in a 
banking environment is provided by Beaver and Venkatachalam (2003) who partition U.S. commercial bank loan fair values into non-discretionary, discretionary and noisy components. They find that the pricing coefficient associated with the discretionary loan component of fair values is negative when managerial intent shows opportunism. Similarly, Nissim (2003) finds evidence that banks manage their loan fair values. The estimated extent of such overstatement of loan fair values varied with regulatory capital requirements and changes in the rate of credit losses. Shen and Huang (2011) provide an illustration of these practices in an Australian context. They compiled a sample of 441 firm year observations of Australian commercial banks covering the period from 1991 until 2001 and show that Australian banks also manage their loan loss provisions for capital management and earnings management purposes. Shen and Huang (2011) conclude in particular that the reported earnings of Australian banks may not provide a true reflection of their underlying profitability. Suffice it to say that there are many other studies which have shown that when accounting information is subjective in nature and managerial discretion is allowed over it, that managers may be more likely to generate intentional biases in their estimates of accounting aggregates (e.g., Aboody, Barth and Kasznik, 2006; Bartov, Mohanram and Nissim, 2007). The important point here is that management's ability to manipulate the accruals component of a firm's earnings figure will more than likely cloud the relationship between the firm's current fair values and its future earnings. This contrasts with the firm's statement of cash flows where there is much less potential for manipulation by management. Given this, one would expect there to be a much tighter relationship between a firm's current fair values and its future operating cash flows, than will be the case with its future operating earnings. This expectation is in fact borne out by the empirical results summarized in subsequent sections of this paper. 
It is generally accepted that the market value of a firm's equity will be equal to the present value of its expected future cash flows and that this should be closely aligned to the fair value of its net assets (Barth, 2000:19; Ryan, 2008:12). Given this one would expect a positive association between the net fair values summarized on the firm's balance sheet and the future performance of the firm, as measured by its future operating cash flows and its future operating earnings. This suggested positive relationship however, could be called into question if there is measurement error in the way fair value estimates have been determined or if the estimated fair values are biased due to opportunistic behavior on the part of firm management. In light of the above arguments, we advance hypotheses 1 as follows:

\section{Hypotheses 1:}

H1a: The current net asset fair values of on-balance sheet financial instruments of banks have a positive association with the future years' cash flows of such banks.

H1b: The current net asset fair values of on-balance sheet financial instruments of have a positive association with the future years' earnings of such banks. ${ }^{9}$

\subsubsection{Impact of the 2007/2008 GFC on the relationship between fair values and future cash} flows and earnings.

We have previously observed how fair value estimation may be compromised by financial crises (such as the GFC of 2007/2008) where markets become increasingly illiquid and valuations more volatile and problematic. It has been argued in particular that the implementation of SFAS 157 in November, 2007 exacerbated an already highly volatile

\footnotetext{
${ }^{9}$ Future cash flows and future earnings are 1, 2 and 3 year ahead earnings/cash flows. Hence if the "current" year was 1996, future cash flows and earnings would be cash flows and earnings in years 1997, 1998 and 1999 , respectively.
} 
market situation and contributed to the contagion phenomenon which was then emerging and under which firms were forced to sell off assets at artificially discounted prices in order to secure the capital necessary to finance their continuing operations (Ryan, 2008; Plantin, Sapra and Shin, 2008). In such circumstances there may be an increasing ambiguity in the relationship between an asset's fair value and its future cash flows. Given this, we also formulate hypotheses 2 relating to the impact that the GFC had on the relationship between the fair values summarized in banks' financial statements and their future operating cash flows and future operating earnings as follows:

\section{Hypotheses 2:}

H2a: The global financial crises of years 2007 and 2008 had a negative impact on the association between the current net asset fair values of on-balance sheet financial instruments of banks and the future years' cash flows of such banks.

H2b: The global financial crises of years 2007 and 2008 had a negative impact on the association between the current net asset fair values of on-balance sheet financial instruments of banks and the future years' earnings of such banks.

\section{Methodology}

\subsection{Study Period and Sample Selection}

Our empirical analysis covers the sixteen-year period from 1995 to 2011 . The year 1995 was chosen as the starting point for our empirical analysis because, SFAS 107, SFAS 115 and SFAS $119^{10}$ - which were key fair value recognition and disclosure standards relevant to U.S. banks - were all in place in 1995 and the sample group of banks were already reporting in the

\footnotetext{
${ }^{10}$ These standards were put in place for compliance by U.S. banks by the FASB between the years 1991 and 1994.
} 
notes to their financial statements the fair value estimates of their on-balance sheet financial instruments. Considering that the study involves the prediction of future period cash flows and earnings, it is important for the empirical analysis that at least every current firm year net fair value disclosure has corresponding cash flows and earnings information at a minimum level of one period ahead and up to a maximum of three periods ahead. ${ }^{11}$ Thus, for example, current net fair value disclosures for 2011 will be related to the future cash flows and earnings in 2012,2013 and 2014.

We source our data from the COMPUSTAT Bank Fundamentals Annual database for U.S. banks with a minimum size of \$US150 million in total assets as of 1995 and who file their financial statements with the Securities and Exchange Commission. The benchmark size of the banks included in the sample is based on the SFAS 107 implementation size criterion of \$US150 million in total assets for financial institutions to disclose the fair values of their financial assets and liabilities (FASB, 1991; Eccher et al., 1996) ${ }^{12}$. The form 10-K EDGAR files (annual reports) of the identified banks were then searched using the DirectEdgar software extraction engine to obtain the fair values of on-balance sheet financial instruments made in the notes to the financial statements. Financial data such as operating cash flows and earnings, total assets, tier 1 capital, number of common shares on issue, etc. were collected from the COMPUSTAT Bank Fundamentals Annual database. We exclude firms that had missing data for any of the relevant variables.

\footnotetext{
${ }^{11}$ Data availability is a constraint on the number of periods ahead that one can test the relationship between fair values and future earnings and cash flows. However, with 3 periods into the future, a sample size large enough to guarantee the "degrees of freedom" necessary to conduct our empirical analysis can be obtained.

${ }^{12}$ Despite the minimum size of \$US150 million in total assets, there remains a representative set of banks included in the sample as some U.S. banking institutions can be very large with a national presence across the country, while other banks operate on a smaller scale, regionally or in a single state. To differentiate the sample banks based on their relative size, the sample is divided into two groups: 'large banks' with total assets above the median total assets of the sample banks and 'small banks' with total assets below the median (Song et al., 2010).
} 
Our final sample consists of 232 banks (1,642 firm-years) with future cash flows at time $t+1$, 227 banks (1,579 firm-years) with future cash flows at time $t+2$ and 226 banks (1,518 firmyears) with future cash flows at time $t+3$. The operating earnings sample comprised 217 banks (1,559 firm-years) having future operating earnings at time $t+1,213$ banks $(1,507$ firmyears) with future operating earnings at time $t+2$ and 214 (1,464 firm-years) banks with future operating earnings at time $t+3$.

\subsection{Empirical models}

We test our hypotheses using ordinary least squares to estimate cross-sectional multivariate regression models. The variables involved are continuous in nature and the cross-sectional equations estimated are used to make inferences about the hypothesized relationships between net asset bank fair values, their future operating cash flows and their earnings ${ }^{13}$. The following primary multivariate models ${ }^{14}$ are used to test hypotheses 1 (a) and 1(b):

$C F_{t+q}=a_{0}+a_{1} N F V A_{t}+a_{2} C F_{t}+\alpha_{t}$

$O P_{t+q}=b_{0}+b_{1} N F V A_{t}+b_{2} O P_{t}+\beta_{t}$

where $a_{0}, a_{1}$ and $a_{2}$ are regression coefficients and $\alpha_{t}$ is a stochastic error term. Similarly, $b_{0}, b_{1}$ and $b_{2}$ are regression coefficients and $\beta_{t}$ is a stochastic error term. We estimate Eq. (1) and (2) separately for the operating cash flows and operating earnings over each of the three

\footnotetext{
${ }^{13}$ Considering that the ex ante realized operating income and operating cash flows are unobservable, we use the ex post realized operating income and operating cash flows as proxies for the ex ante values.

${ }^{14}$ Many studies in this area scale variables on both sides of the regression equation by the book value of equity, stock price, the book value of total assets or something similar in order to reduce heteroscedasticity (Jones 1991, 212; Eccher et al., 1996; Nelson, 1996). However, Pearson (1897) demonstrates that this procedure leads to biased parameter estimates of the levels relationship and an $\mathrm{R}^{2}$ statistic which is biased upwards due to the effects of spurious correlation. Given this, the data employed in our regression analyses were transformed using the inverse hyperbolic sine function. This transformation renders the data more compatible with the assumptions of the general linear regression model (Laubscher, 1961). Most important, however, is that in comparison with other common transformations the inverse hyperbolic sine transformation can accommodate negative values.
} 
year horizons, from year $t$ to year $t+q$, where $q=1,2,3$. Accordingly, $C F_{t+q}$ is operating cash flows, one, two and three years ahead. Operating cash flows represent the net cash flows arising from operating activities and includes interest received, fees and commissions received and other income received in the ordinary course of bank business, less interest paid, cash paid to suppliers and employees and other expenses incurred in the ordinary course of business. $O P_{t+q}$ is operating profit (or operating income ${ }^{15}$ ), one, two and three years ahead. Following Aboody et al., (1999), the proxy utilized as operating income is the net profit before taxes, which is defined for a bank to be total interest income plus non-interest income less total interest expense, non-interest expense and provision for loan losses. Income tax expense is excluded because of the focus on the operating performance of the banks.

$N F V A_{t}$ is net asset bank fair values. This is the summation of ten classes of fair value financial instrument assets less six classes of fair value financial instrument liabilities that are on the balance sheet of the selected banks. ${ }^{16}$ These figures are reported in accordance with the disclosure requirements of SFAS 107, in the notes to the financial statements section of the 10-K report forms (the banks' annual report), submitted by the banks to the Securities and Exchange Commission as summarized in the EDGAR database.

We include the current year cash flow from operations $\left(C F_{t}\right)$ and the current year operating income $\left(O P_{t}\right)$ as independent control variables as there is an expected relationship between

\footnotetext{
${ }^{15}$ We use the term operating profit, operating income and operating earnings interchangeably to represent the same concept.

${ }^{16}$ The ten classes of fair value financial instrument assets include: 1. Cash and cash equivalents (including due from banks and interest-bearing deposits with other banks). 2. Federal funds sold and securities purchased under resale agreements. 3. Federal Reserve and Federal Home Loan Bank Stocks. 4. Investment securities available for sale. 5. Investment securities held to maturity. 6. Investment securities held for trading. 7. Loans held for sale. 8. Net loans. 9. Mortgage servicing rights; and 10. Other short-term financial assets such as interest receivables and customer acceptances due. The six classes of fair value of financial instrument liabilities are: 1 . Deposits. 2. Federal funds purchased and securities sold under agreements to repurchase. 3. Federal Home Loan Bank Advances. 4. Long-term debt. 5. Short-term debt; and 6. Other short-term liabilities such as interest payables and other financial instrument liabilities.
} 
the current year cash flows from operations (and current earnings) and associated future cash flows (and future earnings) (Aboody et al., 1999). Thus, by including the current cash flow from operations and earnings in the models as independent variables, we control for the timeseries properties of operating cash flows and earnings that might affect future operating cash flows and earnings.

We test hypotheses 2(a) and 2(b), by employing the multivariate regression models summarized in Eq. (3) and (4) as follows:

$C F_{t+q}=m_{0}+m_{1} G F C Y r+m_{2} N F V A_{t}+m_{3} C F_{t}+\lambda_{t}$

$O P_{t+q}=n_{0}+n_{1} G F C Y r+n_{2} N F V A_{t}+n_{3} O P_{t}+\eta_{t}$

where $m_{0}, m_{1} \quad m_{2}$ and $m_{3}$ are regression coefficients and $\lambda_{t}$ is a stochastic error term. Similarly $n_{0}, n_{1} n_{2}$ and $n_{3}$ are regression coefficients and $\eta_{t}$ is a stochastic error term. We include the indicator variable, $G F C Y r$, to capture the effects of the global financial crises covering the years from 2007 until 2008. The GFCYr indicator variable is assigned a value of 1 for the years 2007 and 2008 and 0 otherwise. The inclusion of the GFCYr indicator variable is designed to evaluate the effects of the GFC on the underlying relationships between net asset bank fair values and the future performance of the banks included in our sample.

\subsubsection{Additional Control Variables}

In order to control for the influence of characteristics which are peculiar to each bank we follow prior research in assessing the influence of bank size, capital adequacy (which reflects leverage and financial risk) and growth prospects on our modeling procedures. We control for bank size by following the approach of Song et al. (2010) and Evans et al. (2014) both of 
whom implement their regression models on 'large banks' with total assets above the median total assets of the entire sample and then separately on 'small banks' with total assets below the median ${ }^{17}$. Similarly, to control for bank capital adequacy we follow Song et al. (2010) by using the Tier 1 capital ratio ${ }^{18}$ as a proxy for capital adequacy based on regulatory requirements. We implement separate regression models for 'Highly capitalized banks' with a Tier 1 capital ratio above the median total Tier 1 capital ratio of the entire sample of banks and 'Low capitalized banks' with a Tier 1 capital ratio below the median. To control for the growth prospects of our sampled banks, we follow Song et al. (2010) and Eccher et al. (1996) by including a growth variable in our regressions. The growth variable is represented by the growth in bank total assets and also, the growth in bank net loans. Here $G R W$ (asset growth) is defined as the logarithm of bank total assets at time $t$ divided by bank total assets at time $(t$ 1) where time $t$ represents the particular "year" during the study period. The estimates of the regression equations that include the growth variable were then compared with the original models which did not include the growth variable.

\subsubsection{Data transformation and regression diagnostics}

The inverse hyperbolic sine $\left[\operatorname{arsinh}(x)\right.$ or $\left.\sinh ^{-1}(x)\right]$ transformation was used to stabilize the variance of the error terms in our regression equations in order to render them more compatible with the classical least squares regression assumptions (Laubscher, 1961; Sokal and Rohlf, 1981:859). Considering the scale effects involved in these kinds of datasets and

\footnotetext{
${ }^{17}$ Some other studies have controlled for bank size by using the logarithm of the balance sheet value of total assets as an independent variable (Aboody et al, 1999; Eccher et al., 1996), while Bratten et al. (2012) employed a similar approach to our study with a different classification threshold, with banks that have total assets in excess of \$US10 billion classified as 'large' and banks with total assets of less than \$US10 billion classified as 'small'.

18 Tier 1 capital ratio refers to banks' core capital (includes equity capital and disclosed reserves) divided by banks' risk weighted assets (i.e. all assets held by a bank weighted by credit risk).
} 
with the possibility of very large bank values driving the regressions results, scaling the data either by total assets or the number of shares on issue has often been used in prior studies (Song et al., 2010; Aboody et al., 1999; Barth and Clinch, 2009). Moreover, in order to reduce problems with skewness and possible heteroscedasticity, continuous positive variables are often transformed by use of the logarithmic function (Aboody et al., 1999; Eccher et al., 1996). However, here we again prefer to use the $\operatorname{arsinh}(x)$ transformation because in contrast to the logarithmic function, the $\operatorname{arsinh}(x)$ transformation accommodates negative and zero values for all variables. Moreover, for large positive values of $x$ the $\operatorname{arsinh}(x) \operatorname{transformation}$ asymptotically approaches the value $\log (2 x)=\log (\mathrm{x})+\log (2)$ and therefore, has many of the properties one normally associates with the logarithmic transformation. The $\operatorname{arsinh}(x)$ transformation also significantly decreases skewness in all our variables and thus reduces the departure from the normal distribution assumptions on which our significance tests are based. Figure 1 plots the logarithmic transformation against $\operatorname{arsinh}(\mathrm{x})-\log (2)$. Note how the two graphs quickly converge thereby confirming the logarithmic nature of the inverse hyperbolic sine transformation. Moreover, note how the inverse hyperbolic sine accommodates negative values in contrast to the logarithmic transformation which cannot accommodate them. Finally, whilst the inverse hyperbolic sine transformation reduces the adverse impact that heteroscedasticity will have on our estimation procedures, the t-statistics for the estimated coefficients in our regression equations were all based on the corrected standard errors obtained from the White robust adjustment procedure (White, 1980).

We also tested the matrix of correlation coefficients across the independent variables for evidence of co-linear independent variables. Here all variance inflation factors (Vif) are lower than 10 - the level at which the stability of the regression procedures are generally regarded as 
Figure 1: Logarithmic and Inverse hyperbolic sine transformation graph

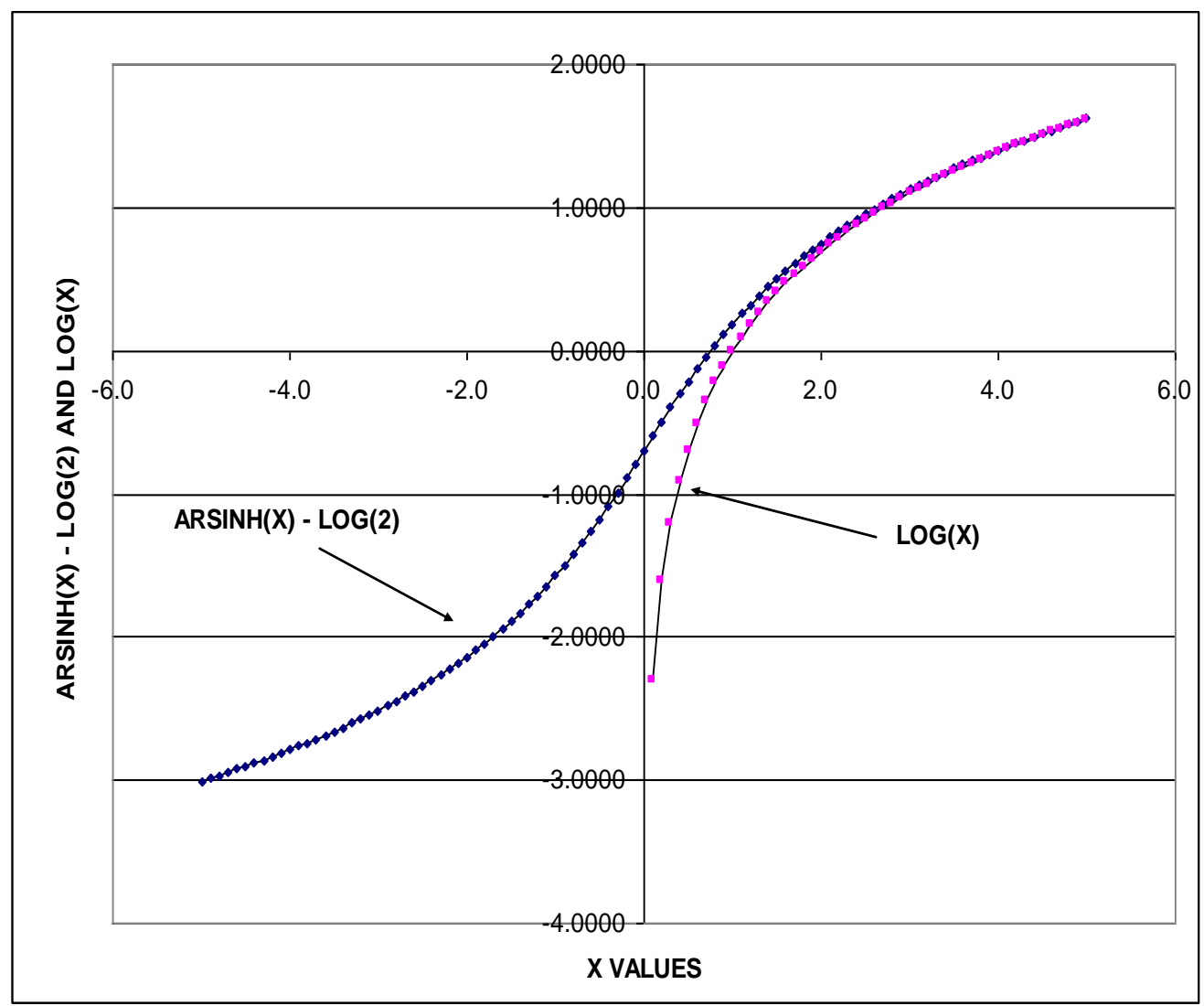


being seriously compromised (Coenders and Saez, 2000). Similarly, all condition indexes fall well below the value of 30 which is generally regarded as establishing the existence of colinear independent variables (Belsley, Kuh and Welsch, 1980; Belsley, 1982; Coenders and Saez, 2000). Finally, we also address the possibility that residuals might be correlated across years and/or across firms by employing standard errors and related t-statistics which are robust to within cluster correlation for the firm year observations in our dataset.

\section{Empirical results}

\subsection{Descriptive statistics}

Unreported descriptive statistics for our raw sample data show that the standard deviation, skewness and kurtosis statistics were very large and that the standardized skewness and standardized kurtosis measures were both significantly different from zero at any reasonable level of significance. This indicates that is it highly unlikely our raw data are drawn from a normal distribution. In order to address this problem and also address issues of heteroscedasticity, we apply the inverse hyperbolic sine transformation to our data, as discussed in section 4.2.1. The inverse hyperbolic sine transformation substantially reduces the variability in the data (as measured by the standard deviation) and significantly reduces the standardized skewness and standardized kurtosis measures associated with the untransformed data, thereby moderating issues of heteroscedasticity and making the data employed in our empirical analyses more compatible with the assumptions which underscore the general linear regression model.

A summary of the descriptive statistics relating to the transformed data on which our empirical analysis is based (that is, after applying the inverse hyperbolic sine transformation) are presented in Tables 1 and 2. Thus, panel A1 of Table 1 shows that the average annual one 
year ahead transformed future operating cash flows $\left(C F_{t+1}\right)$ across the 1,642 firm-years comprising our sample is 3.528 whilst the average transformed net fair value assets $\left(N F V A_{t}\right)$ associated with one year ahead operating cash flows is 4.527. In Table 2 Panel B1, the average annual one year ahead transformed future operating earnings $\left(O P_{t+1}\right)$ across the 1,559 firm-years in our sample is 3.650 whilst the average transformed net fair value assets $\left(N F V A_{t}\right)$ associated with one year ahead operating earnings is 4.541 . Note also how the median values of the net fair value assets, $N F V A_{t}$, across the samples are positive, signifying that more than half the bank-year observations in our samples report financial asset fair values that exceed their financial liabilities fair values. Untabulated results also show that the average raw annual one year ahead future operating cash flows $\left(C F_{t+1}\right)$ across the 1,642 firm-years in our sample amounts to $\$ 148.3$ million. The average raw annual two year ahead operating cash flows $\left(C F_{t+2}\right)$ increases to $\$ 174.8$ million across the 1,579 firm-years comprising our sample and the average raw annual three year ahead operating cash flows $\left(C F_{t+3}\right)$ increases to $\$ 183.6$ million across the 1,518 firm-years. The average raw net fair value assets $\left(N F V A_{t}\right)$ associated with one year ahead operating cash flows amounts to $\$ 407.3$ million and the average raw net fair value assets $\left(N F V A_{t}\right)$ associated with two and three year ahead operating cash flows amount to \$347.1 million and \$276.6 million, respectively. Untabulated results also show that the average raw annual one year ahead future operating earnings $\left(O P_{t+1}\right)$ across the 1,559 firmyears comprising our sample is $\$ 135.3$ million and the average raw annual two year ahead operating earnings $\left(O P_{t+2}\right)$ increases to $\$ 144.1$ million across the 1,507 firm-years comprising our sample. The average raw annual three year ahead operating earnings $\left(O P_{t+3}\right)$ is $\$ 141.5$ million across our sample size of 1,464 firm-years. The average raw net fair value assets $\left(N F V A_{t}\right)$ associated with one year ahead operating earnings is $\$ 367.2$ million and the average raw net fair value assets $\left(N F V A_{t}\right)$ associated with two and three year ahead operating earnings amounts to $\$ 305.4$ million and \$ 256.8 million, respectively. 


\begin{tabular}{|c|c|c|c|c|c|c|c|c|}
\hline \multicolumn{9}{|c|}{$\begin{array}{c}\text { Table } 1 \\
\text { Descriptive Statistics for the operating cash flow models }{ }^{19}\end{array}$} \\
\hline \multicolumn{9}{|c|}{ Panel A1: Descriptive statistics for regression models in Eq(1) and Eq (3) at year $t+1$} \\
\hline Variable & Mean & Std. Dev. & Minimum & Q1 & Median & Q3 & Maximum & $\begin{array}{c}\mathrm{N} \\
\text { (Firm-Years) }\end{array}$ \\
\hline$C F_{t+1}$ & 3.528 & 2.739 & -10.581 & 2.913 & 3.798 & 4.968 & 10.877 & 1642 \\
\hline$N F V A_{t}$ & 4.527 & 3.145 & -11.042 & 4.140 & 4.945 & 6.121 & 12.245 & 1642 \\
\hline$G F C Y r$ & 0.050 & 0.218 & 0.000 & 0.000 & 0.000 & 0.000 & 1.000 & 1642 \\
\hline$C F_{t}$ & 3.385 & 2.746 & -10.581 & 2.774 & 3.671 & 4.848 & 10.127 & 1642 \\
\hline \multicolumn{9}{|c|}{ Panel A2: Descriptive statistics for regression models in Eq(1) and Eq (3) at year $t+2$} \\
\hline Variable & Mean & Std. Dev. & Minimum & Q1 & Median & Q3 & Maximum & $\begin{array}{c}\mathbf{N} \\
\text { (Firm-Years) }\end{array}$ \\
\hline$C F_{t+2}$ & 3.617 & 2.728 & -10.581 & 2.969 & 3.856 & 5.125 & 10.877 & 1,579 \\
\hline$N F V A_{t}$ & 4.528 & 3.112 & -11.042 & 4.126 & 4.924 & 6.104 & 12.004 & 1,579 \\
\hline$G F C Y r$ & 0.047 & 0.213 & 0.000 & 0.000 & 0.000 & 0.000 & 1.000 & 1,579 \\
\hline$C F_{t}$ & 3.377 & 2.725 & -10.339 & 2.767 & 3.661 & 4.827 & 10.127 & 1,579 \\
\hline \multicolumn{9}{|c|}{ Panel A3: Descriptive statistics for regression models in Eq(1) and Eq (3) at year $t+3$} \\
\hline Variable & Mean & Std. Dev. & Minimum & Q1 & Median & Q3 & Maximum & $\begin{array}{c}\mathrm{N} \\
(\text { Firm-Years })\end{array}$ \\
\hline$C F_{t+3}$ & 3.662 & 2.783 & -10.581 & 3.000 & 3.949 & 5.179 & 10.877 & 1,518 \\
\hline$N F V A_{t}$ & 4.502 & 3.116 & -11.042 & 4.104 & 4.903 & 6.071 & 11.830 & 1,518 \\
\hline$G F C Y r$ & 0.046 & 0.210 & 0.000 & 0.000 & 0.000 & 0.000 & 1.000 & 1,518 \\
\hline$C F_{t}$ & 3.328 & 2.752 & -10.339 & 2.731 & 3.652 & 4.794 & 9.762 & 1,518 \\
\hline
\end{tabular}

${ }^{19}$ All variables except for the indicator variables have been transformed using the inverse hyperbolic sine function. 
Table 2

Descriptive Statistics for the operating earnings models ${ }^{20}$

Panel B1: Descriptive statistics for regression models in $\mathrm{Eq}(2)$ and $\mathrm{Eq}(4)$ at year $t+1$

\begin{tabular}{|l|r|r|r|r|r|r|r|r|}
\hline \multicolumn{1}{|c|}{ Variable } & Mean & Std. Dev. & Minimum & \multicolumn{1}{c|}{ Q1 } & Median & \multicolumn{1}{c|}{ Q3 } & Maximum & $\begin{array}{c}\text { N } \\
\text { (Firm-Years) }\end{array}$ \\
\hline$O P_{t+1}$ & 3.650 & 2.415 & -8.649 & 2.892 & 3.831 & 4.859 & 9.525 & 1,559 \\
\hline$N F V A_{t}$ & 4.541 & 3.175 & -11.257 & 4.152 & 4.963 & 6.163 & 12.004 & 1,559 \\
\hline$G F C Y r$ & 0.053 & 0.223 & 0.000 & 0.000 & 0.000 & 0.000 & 1.000 & 1,559 \\
\hline$O P_{t}$ & 3.601 & 2.302 & -7.811 & 2.803 & 3.724 & 4.752 & 9.484 & 1,559 \\
\hline
\end{tabular}

Panel B2: Descriptive statistics for regression models in $\mathrm{Eq}(2)$ and $\mathrm{Eq}(4)$ at year $\boldsymbol{t}+2$

\begin{tabular}{|l|r|r|r|r|r|r|r|r|}
\hline \multicolumn{1}{|c|}{ Variable } & Mean & Std. Dev. & Minimum & \multicolumn{1}{c|}{ Q1 } & Median & \multicolumn{1}{c|}{ Q3 } & Maximum & $\begin{array}{c}\text { N } \\
\text { (Firm-Years) }\end{array}$ \\
\hline$O P_{t+2}$ & 3.687 & 2.466 & -8.649 & 2.939 & 3.899 & 4.963 & 9.525 & 1,507 \\
\hline$N F V A_{t}$ & 4.555 & 3.131 & -11.257 & 4.152 & 4.951 & 6.141 & 11.830 & 1,507 \\
\hline$G F C Y r$ & 0.050 & 0.218 & 0.000 & 0.000 & 0.000 & 0.000 & 1.000 & 1,507 \\
\hline$O P_{t}$ & 3.626 & 2.222 & -7.811 & 2.826 & 3.723 & 4.746 & 9.484 & 1,507 \\
\hline
\end{tabular}

Panel B3: Descriptive statistics for regression models in $\mathrm{Eq}(2)$ and $\mathrm{Eq}(4)$ at year $t+3$

\begin{tabular}{|l|r|r|r|r|r|r|r|r|}
\hline \multicolumn{1}{|c|}{ Variable } & Mean & Std. Dev. & Minimum & \multicolumn{1}{c|}{ Q1 } & Median & \multicolumn{1}{c|}{ Q3 } & Maximum & $\begin{array}{c}\text { N } \\
\text { (Firm-Years) }\end{array}$ \\
\hline$O P_{t+3}$ & 3.562 & 2.727 & -9.407 & 2.925 & 3.878 & 5.002 & 9.525 & 1,464 \\
\hline$N F V A_{t}$ & 4.547 & 3.102 & -11.257 & 4.128 & 4.945 & 6.104 & 10.869 & 1,464 \\
\hline$G F C Y r$ & 0.048 & 0.213 & 0.000 & 0.000 & 0.000 & 0.000 & 1.000 & 1,464 \\
\hline$O P_{t}$ & 3.633 & 2.170 & -7.811 & 2.835 & 3.714 & 4.722 & 9.484 & 1,464 \\
\hline
\end{tabular}

${ }^{20}$ All variables except for the indicator variables have been transformed using the inverse hyperbolic sine function. 
Table 3 summarizes the univariate sample correlation coefficients for the transformed operating cash flow data comprising our sample and Table 4 summarizes the sample correlation coefficients for the transformed earnings data. From Table 3 we observe that net asset bank fair values, $N F V A_{t}$, are positively and significantly correlated with future operating cash flows, $C F_{t}$, across the 3 future year time horizons with sample correlation coefficients of $\rho=0.1454$ at $t+1, \rho=0.1715$ at $t+2$ and $\rho=0.1452$ at $t+3$, respectively. Table 4 shows that the correlation coefficients between $N F V A_{t}$, and future operating earnings, $O P_{t}$ are significant and positive with $\rho=0.3037$ at $t+1, \rho=0.2041$ at $t+2$ and $\rho=0.1730$ at $t+3$, respectively. 


\begin{tabular}{|c|c|c|c|}
\hline \multicolumn{4}{|c|}{$\begin{array}{l}\text { Table } 3 \\
\text { Correlation Matrices (Panels A4-A6) for the Cash flow models in Eq(10) and Eq (12) at year } t+1 \\
\text { to } t+3\end{array}$} \\
\hline \multicolumn{4}{|c|}{ Panel A4: Correlation Matrix for Select Variables at year $t+1 \quad(\mathrm{~N}=1,642$ Firm-years $)$} \\
\hline & $C F_{t+1}$ & $N F V A_{t}$ & $C F_{t}$ \\
\hline$C F_{t+1}$ & 1 & & \\
\hline$N F V A_{t}$ & $0.1454 * * *$ & 1 & \\
\hline$C F_{t}$ & $0.4123 * * *$ & $0.1690 * * *$ & 1 \\
\hline \multicolumn{4}{|c|}{ Panel A5: Correlation Matrix for Select Variables at year $t+2 \quad(\mathrm{~N}=1,579$ Firm-years $)$} \\
\hline & $C F_{t+2}$ & $N F V A_{t}$ & $C F_{t}$ \\
\hline$C F_{t+2}$ & 1 & & \\
\hline$N F V A_{t}$ & $0.1715^{* * * *}$ & 1 & \\
\hline$C F_{t}$ & $0.4108 * * *$ & $0.1794 * * *$ & 1 \\
\hline \multicolumn{4}{|c|}{ Panel A6: Correlation Matrix for Select Variables at year $t+3$ (N= 1,518 Firm-years) } \\
\hline & $C F_{t+3}$ & $N F V A_{t}$ & $C F_{t}$ \\
\hline$C F_{t+3}$ & 1 & & \\
\hline$N F V A_{t}$ & $0.1452 * * *$ & 1 & \\
\hline$C F_{t}$ & $0.3547 * * *$ & $0.1864 * * *$ & 1 \\
\hline
\end{tabular}

Table 4

Correlation Matrices (Panels B4-B6) for the Earnings models in Eq(11) and Eq (13) at year $t+1$ to $t+3$

Panel B4: Correlation Matrix for Select Variables at year $t+1 \quad(\mathrm{~N}=1,559$ Firm-years $)$

\begin{tabular}{|c|c|c|c|}
\hline & $O P_{t+1}$ & $N F V A_{t}$ & $O P_{t}$ \\
\hline$O P_{t+1}$ & 1 & & \\
\hline$N F V A_{t}$ & $0.3037 * * *$ & 1 & 1 \\
\hline$O P_{t}$ & $0.6866 * * *$ & $0.3879 * * *$ & \\
\hline
\end{tabular}

Panel B5: Correlation Matrix for Select Variables at year $\boldsymbol{t}+2 \quad(\mathrm{~N}=1,507$ Firm-years $)$

\begin{tabular}{|c|c|c|c|}
\hline & $O P_{t+2}$ & $N F V A_{t}$ & $O P_{t}$ \\
\hline$O P_{t+2}$ & 1 & & \\
\hline$N F V A_{t}$ & $0.2041 * * *$ & 1 & \\
\hline$O P_{t}$ & $0.4999 * * *$ & $0.3783 * * *$ & 1 \\
\hline \multicolumn{4}{|c|}{ Panel B6: Correlation Matrix for Select Variables at year $t+3(\mathrm{~N}=1,464$ Firm-years $)$} \\
\hline & $O P_{t+3}$ & $N F V A_{t}$ & $O P_{t}$ \\
\hline$O P_{t+3}$ & 1 & & \\
\hline$N F V A_{t}$ & $0.1730 * * *$ & 1 & \\
\hline$O P_{t}$ & $0.3159 * * *$ & $0.3733 * * *$ & 1 \\
\hline
\end{tabular}




\subsection{Multivariate analyses}

The empirical implementation of the regression models (1) through (4) used to test the hypothesized relationships summarized in section 3 are presented in Tables 5 and 6 .

\subsubsection{Bank fair values, future operating cash flows and future operating earnings}

\section{(Hypotheses 1a and 1b)}

Our first set of regression results, as summarized in Panel A of Table 5, show the relationship between bank fair values, current year operating cash flows and one, two and three year ahead future operating cash flows over the period from 1995 until 2011. The results provide strong evidence in support of Hypothesis 1a; namely that current year net fair value assets $\left(N F V A_{t}\right)$ are positively associated with future operating cash flows $\left(C F_{t}\right)$. The regression coefficients on current year net fair value assets, $N F V A_{t}$, are positive and significant ${ }^{21}$ with t-statistics of 2.38, 2.72 and 2.13 for the one, two, and three year ahead horizons, respectively. These results are consistent with Aboody et al. (1999) who document a significant positive association between the revaluation of fixed assets of non-financial firms and their future cash flows from operations across a similar three year time horizon. Moreover, we find that the current year cash flow from operations $\left(C F_{t}\right)$ has a positive and significant relationship with the one-, two-, and three-year ahead operating cash flows with t-statistics of $8.55,8.31$ and 7.22 for the one, two, and three year ahead horizons, respectively. This latter finding is consistent with the relevant literature which shows that current year cash flows do have a significant impact on the magnitude of the future cash flows earned by firms.

\footnotetext{
${ }^{21}$ As explained in section 4.2.1, we utilize both the condition index and the variance inflation factor (Vif) to assess whether our regression results have been adversely affected by co-linear independent variables. Generally, we do not find such evidence after running these tests. The condition index (variance inflation factor [Vif]) for the operating cash flow regression results summarised in Panel A of Table 5 are: 3.9542 [1.03] at $t+1,3.9746$ [1.03] at $t+2$ and 3.9233 [1.04] at $t+3$. The condition index (variance inflation factor [Vif]) for the operating earnings regressions shown in Panel B of Table 5 are: 4.1130 [1.18] at $t+1,4.2606$ [1.17] at $t+2$ and 4.3526 [1.16] at $t+3$. The condition indices and Vif factors summarised here are typical of those obtained for all other regression results summarized in this paper and show that there is no evidence our regression procedures have been adversely affected by co-linear independent variables.
} 
Table 5

Panel A: Relationship between bank net fair values and operating cash flows in future years 1, 2 and 3.

\begin{tabular}{|c|c|c|c|c|c|c|c|}
\hline \multirow[b]{2}{*}{ Variable } & \multirow[b]{2}{*}{ Predicted Sign } & \multicolumn{2}{|c|}{ One year ahead } & \multicolumn{2}{|c|}{ Two years ahead } & \multicolumn{2}{|c|}{ Three years ahead } \\
\hline & & Coefficient & t-stat & Coefficient & t-stat & Coefficient & t-stat \\
\hline$N F V A_{t}$ & + & $\begin{array}{c}0.07 * * * \\
(0.029)\end{array}$ & 2.38 & $\begin{array}{c}0.09 * * * \\
(0.033)\end{array}$ & 2.72 & $\begin{array}{l}0.07 * * \\
(0.034)\end{array}$ & 2.13 \\
\hline$C F_{t}$ & + & $\begin{array}{c}0.40 * * * \\
(0.047)\end{array}$ & 8.55 & $\begin{array}{c}0.39 * * * \\
(0.047)\end{array}$ & 8.31 & $\begin{array}{c}0.34 * * * \\
(0.048)\end{array}$ & 7.22 \\
\hline Intercept & & $\begin{array}{l}1.87 * * * \\
(0.202)\end{array}$ & 9.28 & $\begin{array}{l}1.89 * * * \\
(0.219)\end{array}$ & 8.61 & $\begin{array}{c}2.19 * * * \\
(0.229)\end{array}$ & 9.57 \\
\hline $\begin{array}{l}\text { Observations } \\
\text { Adj. R-squared }\end{array}$ & & $\begin{array}{c}1,642 \\
0.17\end{array}$ & & $\begin{array}{c}1,579 \\
0.18\end{array}$ & & $\begin{array}{c}1,518 \\
0.13\end{array}$ & \\
\hline
\end{tabular}

Panel B: Relationship between bank net fair values and operating earnings in future years 1, 2 and 3.

\begin{tabular}{|c|c|c|c|c|c|c|c|}
\hline \multirow[b]{2}{*}{ Variable } & \multirow[b]{2}{*}{ Predicted Sign } & \multicolumn{2}{|c|}{ One year ahead } & \multicolumn{2}{|c|}{ Two years ahead } & \multicolumn{2}{|c|}{ Three years ahead } \\
\hline & & Coefficient & t-stat & Coefficient & t-stat & Coefficient & t-stat \\
\hline$N F V A_{t}$ & + & $\begin{array}{c}0.03 * \\
(0.024)\end{array}$ & 1.38 & $\begin{array}{c}0.01 \\
(0.027)\end{array}$ & 0.51 & $\begin{array}{c}0.06 * \\
(0.036)\end{array}$ & 1.58 \\
\hline$O P_{t}$ & + & $\begin{array}{c}0.70 * * * \\
(0.043)\end{array}$ & 16.48 & $\begin{array}{c}0.55^{* * *} * \\
(0.048)\end{array}$ & 11.34 & $\begin{array}{c}0.37 * * * \\
(0.054)\end{array}$ & 6.77 \\
\hline Intercept & & $\begin{array}{c}0.97 * * * \\
(0.175)\end{array}$ & 5.55 & $\begin{array}{l}1.64 * * * \\
(0.207)\end{array}$ & 7.92 & $\begin{array}{c}1.97 * * * \\
(0.208)\end{array}$ & 9.48 \\
\hline
\end{tabular}

$\begin{array}{lccc}\text { Observations } & 1,559 & 1,507 & 1,464 \\ \text { Adj. R-squared } & 0.47 & 0.25 & 0.10\end{array}$

Robust standard errors in parentheses. ***,**,* indicate statistical significance at the $0.01,0.05$ and 0.10 levels (one-tailed), respectively. Standard errors are corrected using the White robust adjustment procedure.

Panel B of Table 5 summarizes the regression results for the relationship between bank fair values, current year operating earnings and one, two and three year ahead operating earnings over the period from 1995 until 2011. Whilst these results are less compelling than those summarized in Panel A of Table 5 for the operating cash flows, they nonetheless provide confirmatory evidence in support of Hypothesis $1 \mathrm{~b}$; namely, that current year net fair value assets $\left(N F V A_{t}\right)$ are positively associated with future operating earnings $\left(O P_{t}\right)$. Note, in particular, that there is a positive and statistically significant (at the $10 \%$ level) association between the current year net fair value assets $\left(N F V A_{t}\right)$ and the one and three year ahead operating earnings, with t-statistics of 1.38 and 1.58 respectively. This contrasts with the result for two year ahead operating earnings, which is not significant (with a t-statistic of 
0.51). Here it is interesting to compare the average annual operating earnings and average annual operating cash flows over the period from 1995 until 2011, as summarized in Figure 2. This comparison shows that there was a structural change of some significance in the relationship between earnings and cash flows from the year 2006 onwards. Figure 2 shows, in particular, that prior to 2006 average bank operating earnings tended to track average bank operating cash flows very closely and that average operating earnings were much less volatile than average operating cash flows over this period. This supports the previously stated conjecture that earnings represent the normalized (or permanent) cash flows which banks will earn in future periods (Beaver, 1998). However, Figure 2 shows that after 2006 there was a systematic downward bias in average operating earnings relative to bank operating cash flows. This in turn means that current bank operating earnings have become a poor proxy for bank operating cash flows beyond the 2006 period covered by our study ${ }^{22}$. Panel B of Table 5 also shows that current year earnings $\left(O P_{t}\right)$ has a positive and significant relationship with the one, two, and three year ahead operating earnings with t-statistics of 16.48, 11.34 and 6.77, respectively.

\subsubsection{Bank fair values, the GFC years and future banks' performance (Hypotheses $2 a$ and $2 b$ )}

Our second set of results shows the effect of the GFC during the years 2007 and 2008 on the relationship between bank fair values, current year operating cash flows and earnings and one, two and three year ahead future operating cash flows and operating earnings. Panel A of

\footnotetext{
${ }^{22}$ To test for the effects this structural change could have had on the regressions summarised in Panel A and Panel B of Table 5, we included an indicator variable (named POST2006) that is 1 for the years from 2006 onwards and 0 otherwise. Untabulated results for the operating cash flow regressions show that $N F V A_{t}$ remained positive and statistically significant despite the presence of the indicator variable across the three time horizons with t-statistics of $2.58,2.94$ and 2.34 for the one, two, and three year ahead horizons, respectively. This contrasts with our results for the operating earnings regressions, where we find that the indicator variable POST2006 was negative and statistically significant for the one and two year ahead horizons and marginally significant at the three year ahead horizon with t-statistics of $-6.41,-5.55$ and -1.53 , respectively). Moreover, the statistical significance of $N F V A_{t}$ improved slightly after the indicator variable POST2006 was included in the regressions - particularly at the one and three year ahead horizons.
} 
Table 6 shows that the relationship between the GFC indicator variable (GFCYr) and operating cash flows $\left(C F_{t}\right)$ in the first and second year ahead time horizons is not statistically significant. This contrasts with the relationship between the GFC indicator variable and the three year ahead operating cash flows which is positive and highly significant. These results are somewhat surprising as one would expect the GFC to have had a negative impact on the future operating cash flows of banks.

These results are also supported by Figure 2, which shows that at the height of the GFC (the years 2007 and 2008) there was only a relatively minor decline in average operating cash flows of the banks comprising our sample. The results also show that the GFC did not appear to have a significant impact on the underlying relationship between the net fair value assets of the banks and their future operating cash flows as net fair value assets continued to have a strong and positive association with future operating cash flows across the three year ahead time horizons examined in our study. 
Table 6

Panel A: Relationship between bank net fair values and operating cash flows in future years 1, 2 and 3 incorporating an indicator variable $G F C Y r$ for the 2007/2008 global financial crises.

\begin{tabular}{|c|c|c|c|c|c|c|c|}
\hline \multirow[b]{2}{*}{ Variable } & \multicolumn{3}{|c|}{ One year ahead } & \multicolumn{2}{|c|}{ Two years ahead } & \multicolumn{2}{|c|}{ Three years ahead } \\
\hline & Predicted Sign & Coefficient & t-stat & Coefficient & t-stat & Coefficient & t-stat \\
\hline$G F C Y r$ & - & $\begin{array}{c}-0.07 \\
(0.329)\end{array}$ & -0.22 & $\begin{array}{c}0.12 \\
(0.360)\end{array}$ & 0.32 & $\begin{array}{c}0.83 * * * \\
(0.283)\end{array}$ & 2.92 \\
\hline$N F V A_{t}$ & + & $\begin{array}{c}0.07 * * * \\
(0.029)\end{array}$ & 2.35 & $\begin{array}{c}0.09 * * * \\
(0.033)\end{array}$ & 2.73 & $\begin{array}{l}0.08 * * \\
(0.034)\end{array}$ & 2.25 \\
\hline$C F_{t}$ & + & $\begin{array}{c}0.40 * * * \\
(0.047)\end{array}$ & 8.53 & $\begin{array}{c}0.39 * * * \\
(0.047)\end{array}$ & 8.28 & $\begin{array}{c}0.34 * * * \\
(0.048)\end{array}$ & 7.14 \\
\hline Intercept & & $\begin{array}{l}1.88 * * * \\
(0.202)\end{array}$ & 9.29 & $\begin{array}{l}1.88 * * * \\
(0.220)\end{array}$ & 8.57 & $\begin{array}{c}2.15 * * * \\
(0.229)\end{array}$ & 9.36 \\
\hline Observations & & 1,642 & & 1,579 & & 1,518 & \\
\hline Adj. R-squared & & 0.17 & & 0.18 & & 0.13 & \\
\hline
\end{tabular}

Panel B: Relationship between bank net fair values and operating earnings in future years 1, 2 and 3 incorporating an indicator variable GFCYr for the 2007/2008 global financial crises.

\begin{tabular}{|c|c|c|c|c|c|c|c|}
\hline \multirow[b]{2}{*}{ Variable } & \multirow[b]{2}{*}{ Predicted Sign } & \multicolumn{2}{|c|}{ One year ahead } & \multicolumn{2}{|c|}{ Two years ahead } & \multicolumn{2}{|c|}{ Three years ahead } \\
\hline & & Coefficient & t-stat & Coefficient & t-stat & Coefficient & t-stat \\
\hline$G F C Y r$ & - & $\begin{array}{c}-2.78 * * * \\
(0.434)\end{array}$ & -6.40 & $\begin{array}{c}-2.72 * * * \\
(0.496)\end{array}$ & -5.48 & $\begin{array}{c}-0.89 * * \\
(0.441)\end{array}$ & -2.02 \\
\hline$N F V A_{t}$ & + & $\begin{array}{c}0.03 * \\
(0.024)\end{array}$ & 1.46 & $\begin{array}{c}0.01 \\
(0.027)\end{array}$ & 0.46 & $\begin{array}{c}0.06 * \\
(0.036)\end{array}$ & 1.54 \\
\hline$O P_{t}$ & + & $\begin{array}{c}0.66 * * * \\
(0.042)\end{array}$ & 15.73 & $\begin{array}{c}0.51 * * * \\
(0.047)\end{array}$ & 10.99 & $\begin{array}{c}0.36 * * * \\
(0.054)\end{array}$ & 6.63 \\
\hline Intercept & & $\begin{array}{l}1.28 * * * \\
(0.172)\end{array}$ & 7.41 & $\begin{array}{c}1.91 * * * \\
(0.199)\end{array}$ & 9.62 & $\begin{array}{c}2.06 * * * \\
(0.203)\end{array}$ & 10.16 \\
\hline Observations & & 1,559 & & 1,507 & & 1,464 & \\
\hline Adj. R-squared & & 0.54 & & 0.31 & & 0.11 & \\
\hline
\end{tabular}


Figure 2:

Relationship between Operating Cash flows and Earnings of banks from 1995-2011

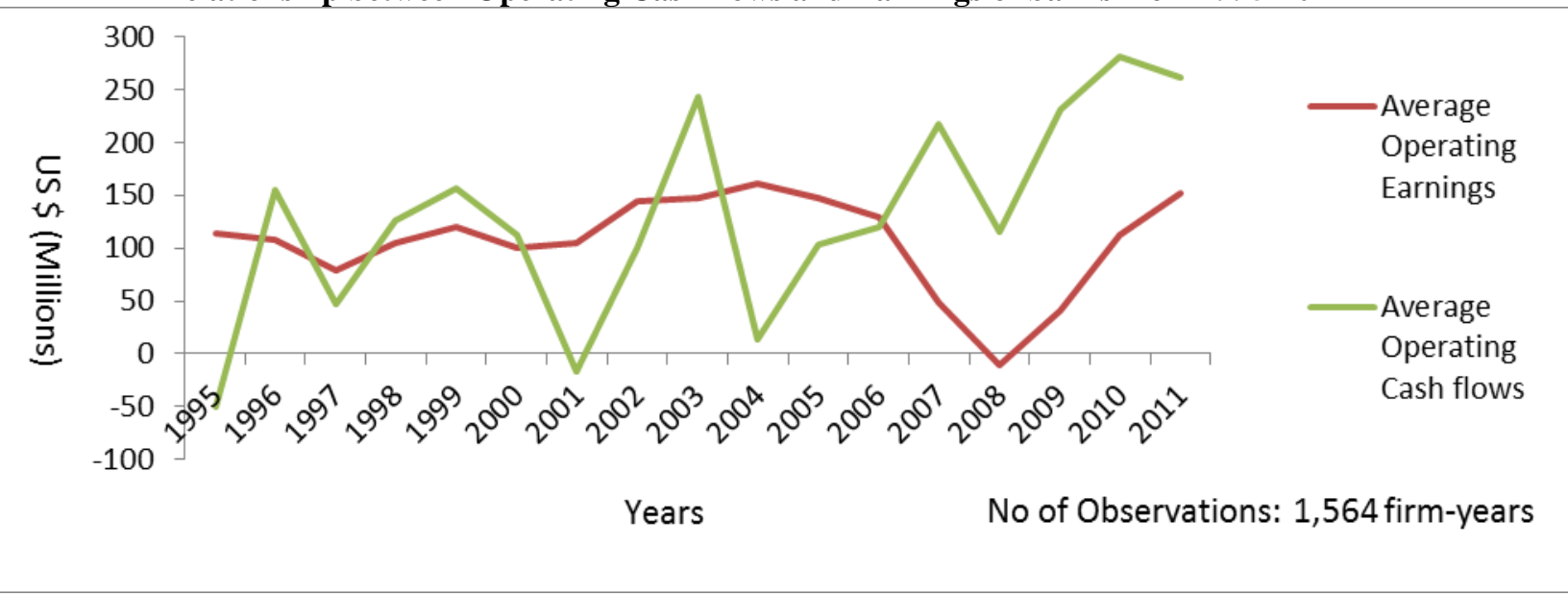


Panel B of Table 6 shows strong evidence that the GFC indicator variable $(G F C Y r)$ has a negative association with future operating $\left(O P_{t}\right)$ earnings. The coefficients associated with the GFC indicator variable are all highly significant with t-statistics of $-6.40,-5.48$ and -2.02 for the one, two and three year ahead operating earnings. These findings are consistent with the hypothesis that the global financial crises had a negative impact on the future operating earnings of banks. The findings also show that the effects of the crises were strongest at the one-year ahead time horizon but then dissipated as the world economy slowly recovered over the subsequent two years. The results also show that the GFC did not appear to have a significant impact on the underlying relationship between the net fair value of bank assets and their future operating earnings as net fair value assets continued to have a modest association with future operating earnings across the three year ahead time horizons comprising our study.

\subsection{The influence of bank characteristics}

\subsubsection{The effects of size}

Tables 7 and 8 present regression results based on the classification of banks by size. 'Large banks' have total assets above the median total assets of the entire sample and 'small banks' have total assets below the median. The results for the large banks subsample are summarized in Panel A1 of Table 7 and show that there is at best a weak association between the net fair value assets $\left(N F V A_{t}\right)$ and one, two and three year ahead operating cash flows. This contrasts with the small banks subsample summarized in Panel A2 of Table 7 which shows that net fair value assets have a highly significant and positive coefficients with t-statistics of $2.50,2.88$ and 2.45 for one, two and three year ahead operating cash flows, respectively. These findings could reflect how quickly the cash flows generated by the banks' net assets are realized. Smaller banks may have incentives to realize cash flows more quickly in order to fund their continuing operations, while larger banks will have a more relaxed attitude towards the timing 
of their cash flows by virtue of the fact that their size will mean they are much less likely to experience liquidity problems than smaller banks.

The results in Table 7 also show that the GFC indicator variable has only a weak association with future operating cash flows and this is so irrespective of the size of the affected banks. Moreover, there is a positive and statistically significant relationship between the current year cash flow from operations and one, two, and three year ahead operating cash flows and this too is so irrespective of the size of the banks. 
Table 7

Relationship between bank net fair values and operating cash flows in future years 1, 2 and 3 .

Panel A1: Large Banks Subsample

\begin{tabular}{|c|c|c|c|c|c|c|c|}
\hline \multirow[b]{2}{*}{ Variable } & \multirow[b]{2}{*}{$\begin{array}{c}\text { Predicted } \\
\text { Sign } \\
\end{array}$} & \multicolumn{2}{|c|}{ One year ahead } & \multicolumn{2}{|c|}{ Two years ahead } & \multicolumn{2}{|c|}{ Three years ahead } \\
\hline & & Coefficient & t-stat & Coefficient & t-stat & Coefficient & t-stat \\
\hline$G F C Y r$ & - & $\begin{array}{c}-0.16 \\
(0.398)\end{array}$ & -0.41 & $\begin{array}{c}0.13 \\
(0.438)\end{array}$ & 0.30 & $\begin{array}{l}0.67 * * \\
(0.354)\end{array}$ & 1.90 \\
\hline$N F V A_{t}$ & + & $\begin{array}{c}0.04 \\
(0.034)\end{array}$ & 1.07 & $\begin{array}{c}0.06 * \\
(0.039)\end{array}$ & 1.53 & $\begin{array}{c}0.05 \\
(0.041)\end{array}$ & 1.11 \\
\hline$C F_{t}$ & + & $\begin{array}{c}0.37 * * * \\
(0.063)\end{array}$ & 5.83 & $\begin{array}{c}0.36 * * * \\
(0.065)\end{array}$ & 5.54 & $\begin{array}{c}0.32 * * * \\
(0.065)\end{array}$ & 4.89 \\
\hline Intercept & & $\begin{array}{c}2.63 * * * \\
(0.354)\end{array}$ & 7.43 & $\begin{array}{c}2.59 * * * \\
(0.380)\end{array}$ & 6.81 & $\begin{array}{c}2.91 * * * \\
(0.391)\end{array}$ & 7.44 \\
\hline Observations & & 819 & & 782 & & 742 & \\
\hline Adj. R-squared & & 0.14 & & 0.14 & & 0.11 & \\
\hline
\end{tabular}

Panel A2: Small Banks Subsample

\begin{tabular}{|c|c|c|c|c|c|c|c|}
\hline \multirow[b]{2}{*}{ Variable } & \multirow[b]{2}{*}{$\begin{array}{l}\text { Predicted } \\
\text { Sign }\end{array}$} & \multicolumn{2}{|c|}{ One year ahead } & \multicolumn{2}{|c|}{ Two years ahead } & \multicolumn{2}{|c|}{ Three years ahead } \\
\hline & & Coefficient & t-stat & Coefficient & t-stat & Coefficient & t-stat \\
\hline$G F C Y r$ & - & $\begin{array}{c}-0.75 \\
(0.519)\end{array}$ & -1.45 & $\begin{array}{l}-0.81^{*} \\
(0.520)\end{array}$ & -1.55 & $\begin{array}{c}0.20 \\
(0.353)\end{array}$ & 0.56 \\
\hline$N F V A_{t}$ & + & $\begin{array}{c}0.09 * * * \\
(0.037)\end{array}$ & 2.50 & $\begin{array}{c}0.12 * * * \\
(0.043)\end{array}$ & 2.88 & $\begin{array}{c}0.11 * * * \\
(0.047)\end{array}$ & 2.45 \\
\hline$C F_{t}$ & + & $\begin{array}{c}0.28 * * * \\
(0.073)\end{array}$ & 3.88 & $\begin{array}{c}0.29 * * * \\
(0.067)\end{array}$ & 4.30 & $\begin{array}{c}0.20 * * * \\
(0.071)\end{array}$ & 2.76 \\
\hline Intercept & & $\begin{array}{c}1.63 * * * \\
(0.244)\end{array}$ & 6.67 & $\begin{array}{c}1.60 * * * \\
(0.255)\end{array}$ & 6.29 & $\begin{array}{c}1.90 * * * \\
(0.249)\end{array}$ & 7.64 \\
\hline Observations & & 823 & & 797 & & 776 & \\
\hline Adj. R-squared & & 0.10 & & 0.12 & & 0.06 & \\
\hline
\end{tabular}

Robust standard errors in parentheses. $* * *, * *, *$ indicate statistical significance at the $0.01,0.05$ and 0.10 levels (one-tailed), respectively. Standard errors are corrected using the White robust adjustment procedure. 
Table 8 replicates the analysis summarized in Table 7 but with one, two and three year ahead operating earnings as the dependent variable. The results summarized in Panel B1 of Table 8 for the large bank sample contrast sharply with those of Table 7 in that they show that irrespective of bank size, the regression coefficients associated with the GFC indicator variable are negative and highly significant with t-statistics of $-6.49,-5.74$ and -2.55 for one, two and three year ahead operating earnings, respectively. Moreover, the results summarized in Panel B2 of Table 8 show that for the small bank sample the regression coefficients associated with the GFC indicator variable are also negative and highly significant with tstatistics of $-3.01,-3.14$ and -2.55 for one, two and three year ahead operating earnings, respectively. Furthermore, consistent with the earlier findings, we find that irrespective of bank size, there remains a weak relationship between the net fair value assets $\left(N F V A_{t}\right)$ and the future operating earnings of the banks across the three time horizons. 
Table 8

Relationship between bank net fair values and operating earnings in future years 1, 2 and 3 .

Panel B1: Large Banks Subsample

\begin{tabular}{|c|c|c|c|c|c|c|c|}
\hline \multirow[b]{2}{*}{ Variable } & \multirow[b]{2}{*}{$\begin{array}{l}\text { Predicted } \\
\text { Sign } \\
\end{array}$} & \multicolumn{2}{|c|}{ One year ahead } & \multicolumn{2}{|c|}{ Two years ahead } & \multicolumn{2}{|c|}{ Three years ahead } \\
\hline & & Coefficient & t-stat & Coefficient & t-stat & Coefficient & t-stat \\
\hline$G F C Y r$ & - & $\begin{array}{c}-3.90 * * * \\
(0.601)\end{array}$ & -6.49 & $\begin{array}{c}-3.74 * * * \\
(0.652)\end{array}$ & -5.74 & $\begin{array}{c}-1.36 * * * \\
(0.535)\end{array}$ & -2.55 \\
\hline$N F V A_{t}$ & + & $\begin{array}{c}0.03 \\
(0.029)\end{array}$ & 1.19 & $\begin{array}{c}0.00 \\
(0.031)\end{array}$ & 0.00 & $\begin{array}{c}0.06^{*} \\
(0.043)\end{array}$ & 1.39 \\
\hline$O P_{t}$ & + & $\begin{array}{c}0.54 * * * \\
(0.058)\end{array}$ & 9.31 & $\begin{array}{c}0.37 * * * \\
(0.061)\end{array}$ & 5.99 & $\begin{array}{c}0.20 * * * \\
(0.065)\end{array}$ & 3.12 \\
\hline Intercept & & $\begin{array}{c}2.21 * * * \\
(0.305)\end{array}$ & 7.26 & $\begin{array}{c}3.17 * * * \\
(0.318)\end{array}$ & 9.94 & $\begin{array}{c}3.27 * * * \\
(0.309)\end{array}$ & 10.61 \\
\hline $\begin{array}{l}\text { Observations } \\
\text { Adj. R-squared }\end{array}$ & & $\begin{array}{l}778 \\
0.52\end{array}$ & & $\begin{array}{r}745 \\
0.27\end{array}$ & & $\begin{array}{l}716 \\
0.06\end{array}$ & \\
\hline
\end{tabular}

Panel B2: Small Banks Subsample

\begin{tabular}{|c|c|c|c|c|c|c|c|}
\hline \multirow[b]{2}{*}{ Variable } & \multirow[b]{2}{*}{$\begin{array}{l}\text { Predicted } \\
\text { Sign } \\
\end{array}$} & \multicolumn{2}{|c|}{ One year ahead } & \multicolumn{2}{|c|}{ Two years ahead } & \multicolumn{2}{|c|}{ Three years ahead } \\
\hline & & Coefficient & t-stat & Coefficient & t-stat & Coefficient & t-stat \\
\hline$G F C Y r$ & - & $\begin{array}{c}-1.37 * * * \\
(0.457)\end{array}$ & -3.01 & $\begin{array}{c}-1.92 * * * \\
(0.612)\end{array}$ & -3.14 & $\begin{array}{c}-1.65 * * * \\
(0.647)\end{array}$ & -2.55 \\
\hline$N F V A_{t}$ & + & $\begin{array}{c}0.02 \\
(0.028)\end{array}$ & 0.77 & $\begin{array}{c}0.05 * \\
(0.035)\end{array}$ & 1.31 & $\begin{array}{c}0.03 \\
(0.036)\end{array}$ & 0.86 \\
\hline$O P_{t}$ & + & $\begin{array}{c}0.67 * * * \\
(0.063)\end{array}$ & 10.59 & $\begin{array}{c}0.48 * * * \\
(0.060)\end{array}$ & 7.99 & $\begin{array}{c}0.33^{* * *} * \\
(0.058)\end{array}$ & 5.65 \\
\hline Intercept & & $\begin{array}{c}0.94 * * * \\
(0.204)\end{array}$ & 4.59 & $\begin{array}{c}1.39 * * * \\
(0.188)\end{array}$ & 7.44 & $\begin{array}{c}1.77 * * * \\
(0.198)\end{array}$ & 8.93 \\
\hline Observations & & 781 & & 762 & & 748 & \\
\hline Adj. R-squared & & 0.45 & & 0.24 & & 0.08 & \\
\hline
\end{tabular}




\subsubsection{The effects of capital adequacy}

Tables 9 and 10 present regression results based on the classification of banks by their capital adequacy. 'Highly capitalized banks' have a Tier 1 capital ratio above the median total Tier 1 capital ratio of the entire sample of banks and 'Low capitalized banks' have a Tier 1 capital ratio below the median. Here Panel A3 of Table 9 shows for banks classified into the high capital ratio subsample, net fair value assets $\left(N F V A_{t}\right)$ has highly significant and positive regression coefficients with t-statistics of $1.56,1.93$ and 2.38 for one, two and three year ahead operating cash flows, respectively. Theses results are in contrast with those summarized in Panel A4 of Table 9 for low capital ratio banks which shows that the coefficients associated with the net fair value of assets variable have t-statistics of only 1.84, 2.18 and 1.36 for one, two and three year ahead operating cash flows. These results suggest that for the subsample of banks in the high capital adequacy classification, the higher the capital adequacy (and hence, the lower the financial risk) the stronger the relationship between the market's long-term expectations about the future cash flows, as indicated by the strong positive relationship in the third-year horizon between net fair value assets and future operating cash flows. This was not the case for low capital adequacy banks. Consistent with the results summarized in Table 7 with respect to bank size, the results in Table 9 also show that the GFC indicator variable (GFCYr) does not have a significant negative impact on the future operating cash flows of banks and this applies irrespective of the capital adequacy levels of the sample banks. 
Table 9

Relationship between bank net fair values and operating cash flows in future years 1, 2 and 3.

Panel A3: Subsample of Banks with High Capital Ratio.

\begin{tabular}{|c|c|c|c|c|c|c|c|}
\hline \multirow[b]{2}{*}{ Variable } & \multirow[b]{2}{*}{$\begin{array}{c}\text { Predicted } \\
\text { Sign } \\
\end{array}$} & \multicolumn{2}{|c|}{ One year ahead } & \multicolumn{2}{|c|}{ Two years ahead } & \multicolumn{2}{|c|}{ Three years ahead } \\
\hline & & Coefficient & t-stat & Coefficient & t-stat & Coefficient & t-stat \\
\hline$G F C Y r$ & - & $\begin{array}{c}-0.40 \\
(0.423)\end{array}$ & -0.94 & $\begin{array}{c}0.13 \\
(0.409)\end{array}$ & 0.31 & $\begin{array}{l}0.63 * * \\
(0.274)\end{array}$ & 2.30 \\
\hline$N F V A_{t}$ & + & $\begin{array}{c}0.07 * \\
(0.045)\end{array}$ & 1.56 & $\begin{array}{c}0.09 * \\
(0.047)\end{array}$ & 1.93 & $\begin{array}{c}0.13 * * * \\
(0.056)\end{array}$ & 2.38 \\
\hline$C F_{t}$ & + & $\begin{array}{c}0.59 * * * \\
(0.060)\end{array}$ & 9.72 & $\begin{array}{c}0.46 * * * \\
(0.061)\end{array}$ & 7.45 & $\begin{array}{c}0.42 * * * \\
(0.064)\end{array}$ & 6.59 \\
\hline Intercept & & $\begin{array}{l}1.09 * * * \\
(0.285)\end{array}$ & 3.83 & $\begin{array}{c}1.56^{* * * *} \\
(0.280)\end{array}$ & 5.59 & $\begin{array}{l}1.53 * * * \\
(0.309)\end{array}$ & 4.94 \\
\hline Observations & & 787 & & 768 & & 740 & \\
\hline Adj. R-squared & & 0.31 & & 0.21 & & 0.22 & \\
\hline
\end{tabular}

Panel A4: Subsample of Banks with Low Capital Ratio.

\begin{tabular}{|c|c|c|c|c|c|c|c|}
\hline \multirow[b]{2}{*}{ Variable } & \multirow[b]{2}{*}{$\begin{array}{c}\text { Predicted } \\
\text { Sign }\end{array}$} & \multicolumn{2}{|c|}{ One year ahead } & \multicolumn{2}{|c|}{ Two years ahead } & \multicolumn{2}{|c|}{ Three years ahead } \\
\hline & & Coefficient & t-stat & Coefficient & t-stat & Coefficient & t-stat \\
\hline$G F C Y r$ & - & $\begin{array}{c}0.02 \\
(0.445)\end{array}$ & 0.04 & $\begin{array}{c}0.06 \\
(0.530)\end{array}$ & 0.11 & $\begin{array}{l}0.95 * * \\
(0.438)\end{array}$ & 2.16 \\
\hline$N F V A_{t}$ & + & $\begin{array}{l}0.07 * * \\
(0.036)\end{array}$ & 1.84 & $\begin{array}{l}0.09 * * \\
(0.042)\end{array}$ & 2.18 & $\begin{array}{c}0.06 * \\
(0.042)\end{array}$ & 1.36 \\
\hline$C F_{t}$ & + & $\begin{array}{c}0.34 * * * \\
(0.058)\end{array}$ & 5.81 & $\begin{array}{c}0.37 * * * \\
(0.060)\end{array}$ & 6.17 & $\begin{array}{c}0.31 * * * \\
(0.060)\end{array}$ & 5.12 \\
\hline Intercept & & $\begin{array}{c}2.20 * * * \\
(0.259)\end{array}$ & 8.49 & $\begin{array}{c}2.04 * * * \\
(0.286)\end{array}$ & 7.12 & $\begin{array}{c}2.38 * * * \\
(0.293)\end{array}$ & 8.14 \\
\hline Observations & & 855 & & 811 & & 778 & \\
\hline Adj. R-squared & & 0.13 & & 0.17 & & 0.11 & \\
\hline
\end{tabular}


Table 10

Relationship between bank net fair values and operating earnings in future years 1, 2 and 3 .

Panel B3: Subsample of Banks with High Capital Ratio.

\begin{tabular}{|c|c|c|c|c|c|c|c|}
\hline \multirow[b]{2}{*}{ Variable } & \multirow[b]{2}{*}{$\begin{array}{c}\text { Predicted } \\
\text { Sign } \\
\end{array}$} & \multicolumn{2}{|c|}{ One year ahead } & \multicolumn{2}{|c|}{ Two years ahead } & \multicolumn{2}{|c|}{ Three years ahead } \\
\hline & & Coefficient & t-stat & Coefficient & t-stat & Coefficient & t-stat \\
\hline$G F C Y r$ & - & $\begin{array}{l}-1.88 * * \\
(0.735)\end{array}$ & -2.56 & $\begin{array}{l}-1.43^{* *} \\
(0.608)\end{array}$ & -2.36 & $\begin{array}{l}-1.15^{*} \\
(0.619)\end{array}$ & -1.85 \\
\hline$N F V A_{t}$ & + & $\begin{array}{c}0.05 \\
(0.053)\end{array}$ & 0.89 & $\begin{array}{c}0.02 \\
(0.040)\end{array}$ & 0.57 & $\begin{array}{c}0.05 \\
(0.046)\end{array}$ & 1.13 \\
\hline$O P_{t}$ & + & $\begin{array}{c}0.63 * * * \\
(0.074)\end{array}$ & 8.47 & $\begin{array}{c}0.48 * * * \\
(0.074)\end{array}$ & 6.55 & $\begin{array}{c}0.38 * * * \\
(0.076)\end{array}$ & 4.98 \\
\hline Intercept & & $\begin{array}{l}1.19 * * * \\
(0.281)\end{array}$ & 4.22 & $\begin{array}{l}1.89 * * * \\
(0.292)\end{array}$ & 6.48 & $\begin{array}{c}2.12 * * * \\
(0.272)\end{array}$ & 7.80 \\
\hline $\begin{array}{l}\text { Observations } \\
\text { Adj. R-squared }\end{array}$ & & $\begin{array}{l}750 \\
0.42\end{array}$ & & $\begin{array}{l}729 \\
0.26\end{array}$ & & $\begin{array}{l}707 \\
0.15\end{array}$ & \\
\hline
\end{tabular}

Panel B4: Subsample of Banks with Low Capital Ratio.

\begin{tabular}{|c|c|c|c|c|c|c|c|}
\hline \multirow[b]{2}{*}{ Variable } & \multirow[b]{2}{*}{$\begin{array}{c}\text { Predicted } \\
\text { Sign }\end{array}$} & \multicolumn{2}{|c|}{ One year ahead } & \multicolumn{2}{|c|}{ Two years ahead } & \multicolumn{2}{|c|}{ Three years ahead } \\
\hline & & Coefficient & t-stat & Coefficient & t-stat & Coefficient & t-stat \\
\hline$G F C Y r$ & - & $\begin{array}{c}-3.32 * * * \\
(0.546)\end{array}$ & -6.09 & $\begin{array}{c}-3.55 * * * \\
(0.693)\end{array}$ & -5.13 & $\begin{array}{c}-0.68 \\
(0.616)\end{array}$ & -1.11 \\
\hline$N F V A_{t}$ & + & $\begin{array}{c}0.04 * \\
(0.024)\end{array}$ & 1.52 & $\begin{array}{c}0.01 \\
(0.035)\end{array}$ & 0.30 & $\begin{array}{c}0.05 \\
(0.048)\end{array}$ & 1.05 \\
\hline$O P_{t}$ & + & $\begin{array}{c}0.66 * * * \\
(0.051)\end{array}$ & 12.90 & $\begin{array}{c}0.52 * * * \\
(0.060)\end{array}$ & 8.70 & $\begin{array}{c}0.35 * * * \\
(0.072)\end{array}$ & 4.90 \\
\hline Intercept & & $\begin{array}{c}1.40 * * * \\
(0.228)\end{array}$ & 6.13 & $\begin{array}{c}1.96 * * * \\
(0.263)\end{array}$ & 7.46 & $\begin{array}{c}1.97 * * * \\
(0.271)\end{array}$ & 7.29 \\
\hline Observations & & 809 & & 778 & & 757 & \\
\hline Adj. R-squared & & 0.60 & & 0.34 & & 0.09 & \\
\hline
\end{tabular}


Table 10 reports the results on capital adequacy for one, two and three year ahead operating earnings as the dependent variable. The GFC indicator variable $(G F C Y r)$ has a significant negative relationship with the future operating earnings of the banks comprising our sample. However, from Panels B3 and B4 of Table 10 it is evident that this negative association is stronger for banks with a low capital ratio (with statistically significant t-statistics of -6.09 and -5.13 for one and two year ahead operating earnings). Hence, although the GFC appears to have had an adverse impact on the future operating earnings of all banks it was particularly severe on banks with low capital adequacy ratios (and therefore high levels of financial risk). Table 10 also shows that bank capital adequacy levels did not appear to have much influence on the relationship between the net fair value of bank assets and the future operating earnings of the banks across any of the three time horizons.

\subsubsection{The effects of growth prospects}

The results summarized in Table 11 for operating cash flows and Table 12 for operating earnings evaluate the influence of banks' growth prospects as represented by GRW (asset growth) on our underlying regression models. Comparing the results summarized in Tables 11 and 12 with those summarized in Table 6 shows that the inclusion of the asset growth variable, $G R W$, does not change any of the conclusions reached in earlier sections of the paper. 
Table 11

Relationship between bank net fair values and operating cash flows in future years 1,2 and 3 with and without an asset growth variable.

\begin{tabular}{|c|c|c|c|c|c|c|c|c|c|c|c|c|c|}
\hline \multirow[b]{3}{*}{ Variable } & \multirow[b]{3}{*}{$\begin{array}{c}\text { Predicted } \\
\text { Sign } \\
\end{array}$} & \multicolumn{4}{|c|}{ One year ahead } & \multicolumn{4}{|c|}{ Two years ahead } & \multicolumn{4}{|c|}{ Three years ahead } \\
\hline & & \multicolumn{2}{|c|}{$E q .3$} & \multicolumn{2}{|c|}{$\begin{array}{c}\text { Eq. } 3 \text { with Growth } \\
\text { Variable. }\end{array}$} & \multicolumn{2}{|c|}{$E q .3$} & \multicolumn{2}{|c|}{$\begin{array}{c}\text { Eq. } 3 \text { with } \\
\text { Growth Variable. }\end{array}$} & \multicolumn{2}{|c|}{ Eq. 3} & \multicolumn{2}{|c|}{$\begin{array}{c}\text { Eq. } 3 \text { with } \\
\text { Growth Variable. }\end{array}$} \\
\hline & & Coefficient & t-stat & Coefficient & t-stat & Coefficient & t-stat & Coefficient & t-stat & Coefficient & t-stat & Coefficient & t-stat \\
\hline$G F C Y r$ & - & $\begin{array}{c}-0.07 \\
(0.329)\end{array}$ & -0.22 & $\begin{array}{c}-0.08 \\
(0.331)\end{array}$ & -0.24 & $\begin{array}{c}0.12 \\
(0.360)\end{array}$ & 0.32 & $\begin{array}{c}0.12 \\
(0.360)\end{array}$ & 0.33 & $\begin{array}{c}0.83 * * * \\
(0.283)\end{array}$ & 2.92 & $\begin{array}{c}0.79 * * * \\
(0.282)\end{array}$ & 2.80 \\
\hline$N F V A_{t}$ & + & $\begin{array}{c}0.07 * * * \\
(0.029)\end{array}$ & 2.35 & $\begin{array}{l}0.06 * * \\
(0.031)\end{array}$ & 2.09 & $\begin{array}{c}0.09 * * * \\
(0.033)\end{array}$ & 2.73 & $\begin{array}{l}0.09 * * * \\
(0.036)\end{array}$ & 2.45 & $\begin{array}{l}0.08 * * \\
(0.034)\end{array}$ & 2.25 & $\begin{array}{c}0.05^{*} \\
(0.033)\end{array}$ & 1.64 \\
\hline$C F_{t}$ & + & $\begin{array}{c}0.40 * * * \\
(0.047)\end{array}$ & 8.53 & $\begin{array}{c}0.41 * * * \\
(0.051)\end{array}$ & 8.07 & $\begin{array}{c}0.39 * * * \\
(0.047)\end{array}$ & 8.28 & $\begin{array}{c}0.38 * * * \\
(0.052)\end{array}$ & 7.25 & $\begin{array}{c}0.34 * * * \\
(0.048)\end{array}$ & 7.14 & $\begin{array}{c}0.35 * * * \\
(0.051)\end{array}$ & 7.00 \\
\hline$G R W$ & + & & & $\begin{array}{c}0.57 * \\
(0.328)\end{array}$ & 1.75 & & & $\begin{array}{c}0.09 \\
(0.519)\end{array}$ & 0.18 & & & $\begin{array}{l}0.79 * * \\
(0.382)\end{array}$ & 2.07 \\
\hline Intercept & $?$ & $\begin{array}{c}1.88 * * * \\
(0.202)\end{array}$ & 9.29 & $\begin{array}{l}1.79 * * * \\
(0.222)\end{array}$ & 8.09 & $\begin{array}{c}1.88 * * * \\
(0.220)\end{array}$ & 8.57 & $\begin{array}{l}1.93 * * * \\
(0.255)\end{array}$ & 7.55 & $\begin{array}{c}2.15 * * * \\
(0.229)\end{array}$ & 9.36 & $\begin{array}{c}2.14 * * * \\
(0.242)\end{array}$ & 8.85 \\
\hline Observations & & 1,642 & & 1,406 & & 1,579 & & 1,358 & & 1,518 & & 1,302 & \\
\hline Adj. R-squared & & 0.17 & & 0.18 & & 0.18 & & 0.17 & & 0.13 & & 0.14 & \\
\hline
\end{tabular}

Robust standard errors in parentheses ***,**, * indicate statistical significance at the $0.01,0.05$ and 0.10 levels (one-tailed), respectively. Standard errors are corrected using the White robust adjustment procedure. 
Table 12

Relationship between bank net fair values and operating earnings in future years 1, 2 and 3 with and without an asset growth variable.

\begin{tabular}{|c|c|c|c|c|c|c|c|c|c|c|c|c|c|}
\hline \multirow[b]{3}{*}{ Variable } & \multirow[b]{3}{*}{$\begin{array}{l}\text { Predicted } \\
\text { Sign }\end{array}$} & \multicolumn{4}{|c|}{ One year ahead } & \multicolumn{4}{|c|}{ Two years ahead } & \multicolumn{4}{|c|}{ Three years ahead } \\
\hline & & \multicolumn{2}{|c|}{$E q .4$} & \multicolumn{2}{|c|}{$\begin{array}{c}\text { Eq. } 4 \text { with Growth } \\
\text { Variable. }\end{array}$} & \multicolumn{2}{|c|}{$E q .4$} & \multicolumn{2}{|c|}{$\begin{array}{c}\text { Eq. } 4 \text { with } \\
\text { Growth Variable. }\end{array}$} & \multicolumn{2}{|c|}{$E q .4$} & \multicolumn{2}{|c|}{$\begin{array}{c}\text { Eq. } 4 \text { with } \\
\text { Growth Variable. }\end{array}$} \\
\hline & & Coefficient & t-stat & Coefficient & t-stat & Coefficient & t-stat & Coefficient & t-stat & Coefficient & t-stat & Coefficient & t-stat \\
\hline$G F C Y r$ & - & $\begin{array}{c}-2.78 * * * \\
(0.434)\end{array}$ & -6.40 & $\begin{array}{c}-2.80 * * * \\
(0.437)\end{array}$ & -6.41 & $\begin{array}{c}-2.72 * * * \\
(0.496)\end{array}$ & -5.48 & $\begin{array}{c}-2.76 * * * \\
(0.498)\end{array}$ & -5.55 & $\begin{array}{l}-0.89 * * \\
(0.441)\end{array}$ & -2.02 & $\begin{array}{l}-0.93 * * \\
(0.440)\end{array}$ & -2.11 \\
\hline$N F V A_{t}$ & + & $\begin{array}{c}0.03 * \\
(0.024)\end{array}$ & 1.46 & $\begin{array}{c}0.04 * \\
(0.026)\end{array}$ & 1.57 & $\begin{array}{c}0.01 \\
(0.027)\end{array}$ & 0.46 & $\begin{array}{c}0.01 \\
(0.030)\end{array}$ & 0.45 & $\begin{array}{c}0.06^{*} \\
(0.036)\end{array}$ & 1.54 & $\begin{array}{c}0.06^{*} \\
(0.040)\end{array}$ & 1.63 \\
\hline$O P_{t}$ & + & $\begin{array}{c}0.66 * * * \\
(0.042)\end{array}$ & 15.73 & $\begin{array}{c}0.63 * * * \\
(0.045)\end{array}$ & 14.15 & $\begin{array}{c}0.51 * * * \\
(0.047)\end{array}$ & 10.99 & $\begin{array}{c}0.48 * * * \\
(0.050)\end{array}$ & 9.68 & $\begin{array}{c}0.36 * * * \\
(0.054)\end{array}$ & 6.63 & $\begin{array}{c}0.32 * * * \\
(0.057)\end{array}$ & 5.62 \\
\hline$G R W$ & + & & & $\begin{array}{l}0.63 * * * \\
(0.229)\end{array}$ & 2.75 & & & $\begin{array}{l}-0.09 \\
(0.341)\end{array}$ & -0.27 & & & $\begin{array}{l}-0.20 \\
(0.409)\end{array}$ & -0.49 \\
\hline Intercept & $?$ & $\begin{array}{l}1.28 * * * \\
(0.172)\end{array}$ & 7.41 & $\begin{array}{l}1.26 * * * \\
(0.191)\end{array}$ & 6.61 & $\begin{array}{l}1.91 * * * \\
(0.199)\end{array}$ & 9.62 & $\begin{array}{l}2.02 * * * \\
(0.222)\end{array}$ & 9.10 & $\begin{array}{c}2.06 * * * \\
(0.203)\end{array}$ & 10.16 & $\begin{array}{c}2.16^{* * *} * \\
(0.227)\end{array}$ & 9.49 \\
\hline Observations & & 1,559 & & 1,338 & & 1,507 & & 1,298 & & 1,464 & & 1,258 & \\
\hline Adj. R-squared & & 0.54 & & 0.53 & & 0.31 & & 0.29 & & 0.11 & & 0.10 & \\
\hline
\end{tabular}

Robust standard errors in parentheses ***,**, * indicate statistical significance at the $0.01,0.05$ and 0.10 levels (one-tailed), respectively. Standard errors are corrected using the White robust adjustment procedure. 


\subsection{Robustness checks}

To check the robustness of the results obtained from estimation of the regression models, we invoked several test procedures. First, we investigated the data employed in the regression analysis for outliers by evaluating the studentized residuals associated with the variables. Following, Belsley et al. (1980) and Fox (1991) the studentized residuals computed from a regression equation with an absolute value greater than 3 are considered to be outliers. We therefore re-estimated the regression models after deleting observations with studentized residuals with an absolute value greater than 3. These procedures had no material effects on the results obtained from the underlying models. Second, we use OLS regression with the cluster option based on bank and year. Untabulated results show that our the results regarding the relationship between the future operating cash flows, future operating earnings and the net fair values across the three time horizons remain unchanged when the cluster regression procedure is applied. Finally, we re-estimated the regression models with alternative data transformations, namely deflation by the balance sheet value of total assets and the balance sheet value of issued common shares. The regression results based on both of these deflation procedures were extremely poor and showed there is at best a tenuous but more commonly, no relationship between the future operating performance (operating cash flows and earnings) of banks and the net asset fair values. This is hardly surprising, as we have previously noted how Pearson (1897) shows that when one implements a regression procedure where some or all of the independent variables and the dependent variable itself are scaled by a common factor, the parameter estimates will be biased and there will also be an element of spurious correlation in the regression relationship. 


\section{Discussion and conclusion}

Focusing on a sample of U.S. banks spanning the period from 1995 until 2011, this paper tests hypotheses in relation to the positive association between U.S. bank fair value disclosures (based on SFAS 107) and banks' future performance as measured by their operating cash flows and earnings over a three-year future time horizon. Our results provide empirical evidence which is compatible with a positive association between bank fair values and future bank performance. This suggests that bank fair values have predictive value in relation to future bank performance (particularly in regard to the banks' operating cash flows). This is consistent with the FASB's view that the asset values shown in firm financial statements should communicate information about the potential future performance of the affected firms (FASB 2010:17). Our empirical results also provide compelling evidence that net asset fair values possess the attribute of performance prediction as argued by Ball (2008); Barth (2006) and Tweedie (2008).

Consistent with H1a, we find that the net asset fair values of on-balance sheet financial instruments of banks are strongly positively associated with the future years' operating cash flows of the banks. The evidence is less compelling when the relationship between bank fair values and future operating earnings (H1b) is considered. This is possibly because, in theoretical terms, fair values represent the expected present value of the future cash flows of the affected asset and/or liability rather than the expected present value of its earnings. Hence, fair values are likely to be more closely aligned to future cash flows in comparison to future earnings. Further, considering the possible effects of managers' ability to manage a firm's reported earnings through the manipulation of discretionary accruals, it is not surprising that the relationship between current fair values and future operating earnings is not as strong as the relationship between current fair values and future operating cash flows. Moreover, the 
weaker relationships between future operating earnings and bank fair values was more evident during the period from year 2006 onwards, where we found that there was a systematic downward bias in operating earnings relative to operating cash flows of the sampled banks. This in turn made operating earnings a poor proxy for operating cash flows during this period.

With respect to our second set of hypotheses, we found for $\mathrm{H} 2 \mathrm{a}$ and $\mathrm{H} 2 \mathrm{~b}$ that the GFC years (2007 and 2008) did not have a significant negative impact on the underlying relationship between the net fair value assets of banks and their future operating cash flows and earnings. This finding is relevant to the debate about the influence of market illiquidity on the quality of the fair value disclosures made by banks. This is because if as a result of an illiquid market the fair values disclosed were not reliable, such disclosures should have very little predictive value. Our findings suggest that the fair value disclosures made during the GFC period based on SFAS 107 continued to exhibit the predictive ability attribute for banks' future performance.

Our analyses further shows that the GFC years also did not have a negative impact on the future operating cash flows of the banks; rather to the contrary, our findings show that at the third year time horizon, the GFC years were positively associated with banks' future operating cash flows. In contrast however, we provide strong evidence, that the GFC years impacted the future operating earnings of banks negatively. The effects of the crises were strongest at the one-year ahead time horizon but then decayed away as the global economy recovered slowly in the subsequent two years. These findings suggest the possibility that while banks implemented significant asset write-downs during the global financial crises period which adversely affected their bottom line earnings, they were at the same time 
building up their operating cash flows. This contradicts the empirical findings of Kim and Kross (2005) who study non-financial firms over the period from 1973 until 2000 and find that the ability of earnings to predict future cash flows has generally been strengthening over time.

Finally, we evaluate the influence of bank characteristics, such as size, capital adequacy and growth prospects on the empirical procedures employed. Our findings show that bank size has a significant impact on the relationship between net asset fair values and banks' future operating cash flows.. However, we find in contrast, that bank size does not make any significant difference to the weak relationship between the net asset fair values and the future operating earnings of the banks. Our findings also show that the higher a bank's capital adequacy (and hence, the lower the bank's financial risk) the stronger the relationship between the market's long-term expectations about the banks' future operating cash flows. The level of financial risk had little impact on the relationship between the net asset fair values and the future operating earnings of banks. Moreover, the growth prospects of banks did not have a significant impact on any of our primary regression models.

\section{Acknowledgements}

We thank S.F. Schantl and seminar participants at the 2016 Financial Markets and Corporate Governance Conference Melbourne for helpful comments and suggestions. We are also grateful to the School of Accountancy, Massey University and School of Accounting and Commercial law, Victoria University of Wellington for financial support. 


\section{References}

Aboody, D., Barth, M. E., and Kasznik, R. (1999). Revaluations of fixed assets and future firm performance: Evidence from the U.K. Journal of Accounting and Economics, 26(1), 149-178.

Aboody, D., Barth, M. E., and Kasznik, R. (2006). Do firms understate stock option-based compensation expense disclosed under SFAS 123? Review of Accounting studies, 11(4), 429461.

Badertscher, B. A., Burks, J. J., and Easton, P. D. (2011). A convenient scapegoat: Fair value accounting by commercial banks during the financial crisis. The Accounting Review, 87(1), $59-90$.

Ball, R. (2008). "Don't Blame the Messenger... Or Ignore the Message". Available at: http://faculty.chicagobooth.edu/brian.barry/igm/ShootingtheMessenger2008-10-12.pdf

Barth, M. E. (1991). Relative measurement errors among alternative pension asset and liability measures. The Accounting Review, 66 (3), 433-463.

Barth, M. E. (1994). Fair Value Accounting: Evidence from investment securities and the market valuation of banks. The Accounting Review, 69 (1), 1-25.

Barth, M. E. (2000). Valuation-based research: implications for financial reporting and opportunities for future research. Accounting and Finance, 40, 7-31.

Barth, M. E. (2006). Including Estimates of the Future in Today's Financial Statements. Accounting Horizons, 20(3), 271-285.

Barth, M. E., Beaver, W. H., and Landsman, W. R. (1996). Value-Relevance of Banks' Fair Value Disclosures under SFAS No. 107. The Accounting Review, 71(4), 513-537.

Barth, M. E., and Clinch, G. (2009). Scale Effects in Capital Markets-Based Accounting Research. Journal of Business Finance \& Accounting, 36(3-4), 253-288.

Bartov, E., Mohanram, P., and Nissim, D. (2007). Managerial discretion and the economic determinants of the disclosed volatility parameter for valuing ESOs. Review of Accounting studies, 12(1), 155-179.

Beaver, W.H (1998). Financial Reporting: An Accounting Revolution. Englewood Cliffs, New Jersey: Prentice Hall.

Beaver, W.H., and Venkatachalam, M. (2003). Differential Pricing of Components of Bank Loan fair values. Journal of Accounting, Auditing and Finance, 18(1), 41-68.

Belsley, D. A. (1982). Assessing the presence of harmful collinearity and other forms of weak data through a test for signal-to-noise. Journal of Econometrics, 20(2), 211-253.

Belsley, D. A., Kuh, E., and Welsch, R. E. (1980). Regression diagnostics: Identifying influential observations and sources of collinearity. New York: John Wiley and Sons.

Bernard, V. L. (1993). Discussion of an investigation of revaluations of tangible long-lived assets. Journal of Accounting Research, 39-45. 
Bratten, B., Causholli, M., and Khan, U. (2012). "Fair Value Accounting and the Predictive Ability of Earnings: Evidence from the Banking Industry". Working paper: www.papers.ssrn.com

Bratten, B., Causholli, M., \& Khan, U. (2016). Usefulness of fair values for predicting banks' future earnings: evidence from other comprehensive income and its components. Review of Accounting Studies, 1-36.

Cheng, K. (2012). Accounting Discretion and Fair Value Reporting: A Study of US Banks' Fair Value Reporting of Mortgage-Backed-Securities. Journal of Business Finance \& Accounting, 39(5-6), 531-566.

Coenders, G., and Saez, M. (2000). Collinearity, heteroscedasticity and outlier diagnostics in regression. Do they always offer what they claim? New Approaches in Applied Statistics, 16, 79-94.

Dechow, P. M., and Schrand, C. M. (2004). Earnings Quality. U.S.A: The Research Foundation of CFA Institute.

Eccher, E. A., Ramesh, K., and Thiagarajan, S. R. (1996). Fair value disclosures by bank holding companies. Journal of Accounting and Economics, 22(1-3), 79-117.

Ehalaiye, D., Tippett, M., and van Zijl, T (2016). "SFAS 157 and the Predictive Value of Bank Fair Values.” Working Paper, School of Accountancy, Massey University.

Evans, M. E., Hodder, L., and Hopkins, P. E. (2014). The Predictive Ability of Fair Values for Future Financial Performance of Commercial Banks and the Relation of Predictive Ability to Banks' Share Prices. Contemporary Accounting Research, 31(1), 3-44.

Fama, E. F. (1970). Efficient Capital Markets: A Review of Theory and Empirical Work.The Journal of Finance, 25(2), 383-417.

Fama, E. F. (1991). Efficient Capital Markets II. Journal of Finance, 46(5), 1575-1617.

Financial Accounting Standards Board (1991). "Disclosures about Fair Value of Financial Instruments"; Statement of Financial Accounting Standards No. 107, Norwalk; CT: FASB.

Financial Accounting Standards Board (2010). "Conceptual Framework of Financial Reporting"; Statement of Financial Accounting Concepts No. 8, Norwalk: CT: FASB.

Fox, J. (1991). Regression diagnostics: An introduction .U.S.A: Sage.

Hitz, J.M. (2007). The Decision Usefulness of Fair Value Accounting - A Theoretical Perspective. European Accounting Review, 16(2), 323 - 362.

International Accounting Standards Board (2010). "Conceptual Framework for Financial Reporting 2010”, London; U.K: IFRS Foundation.

Jensen, M. C. and Meckling, W. H. (1976). Theory of the firm: Managerial behavior, agency costs and ownership structure. Journal of Financial Economics, 3(4), 305-360.

Jones, J. J. (1991). Earnings management during import relief investigations. Journal of Accounting Research, 29(2), 193-228. 
Katz, D.M (2008a). "Fair-Value Accounting's 'Atmosphere of Fear"'. Available at: www.cfo.com; May 19, 2008.

Katz, D.M (2008b). "Herz shouts "Fire!" in the Fair-Value Room". Available at: www.cfo.com; October 22, 2008.

Kim, M., and Kross, W. (2005). The Ability of Earnings to Predict Future Operating Cash Flows Has Been Increasing-Not Decreasing. Journal of Accounting Research, 43(5), 753780 .

Laubscher, N. F. (1961). On stabilizing the binomial and negative binomial variances. Journal of the American Statistical Association, 56(293), 143-150.

Laux, C. (2012). Financial instruments, financial reporting, and financial stability. Accounting and Business Research, 42(3), 239-260.

Laux, C., and Leuz, C. (2009). The Crisis of Fair-Value Accounting: Making Sense of the Recent Debate. Accounting, Organizations and Society, 34(6-7), 826-834.

Leone, M. (2008). "Bankers: Fair Value is like throwing gasoline on a fire". Available at: www.cfo.com; April 14, 2008.

Magnan, M., Menini, A., and Parbonetti, A. (2015). Fair value accounting: information or confusion for financial markets?. Review of Accounting Studies, 20(1), 559-591.

McGregor, W. (2012). Personal reflections on ten years of the IASB. Australian Accounting Review, 22(3), 225-238.

Nelson K.K. (1996). Fair Value Accounting for Commercial Banks: An empirical analysis of SFAS No. 107. The Accounting Review, 71 (2): 161-182.

Nissim, D. (2003). Reliability of Banks' fair value disclosures for loans. Review of Quantitative Finance and Accounting, 20, 355-384.

Ohlson, J. A. (2015). Accounting Research and Common Sense. Abacus,51(4), 525-535.

Pearson, K. (1897). Mathematical contributions to the theory of evolution - on a form of spurious correlation which may arise when indices are used in the measurement of organs. Proc. Roy. Soc. London, 60, 489-498.

Plantin, G., Sapra, H., and Shin, H. S. (2008). Marking-to-Market: Panacea or Pandora's Box? Journal of Accounting Research, 46(2), 435-460.

Ryan, S.G. (2008). Fair Value Accounting: Understanding the issues raised by the credit crunch, Council of Institutional Investors, July, 2008, 1-24.

Shaffer, S. (2010). "Fair value accounting: villain or innocent victim. Exploring the links between fair value accounting, bank regulatory capital and the recent financial crisis". Working paper: Quantitative analysis unit, Federal Reserve Bank of Boston.

Shen, C. H. and Huang, Y.L. (2011). Effects of earnings management on bank cost of debt. Accounting \& Finance, 53(1), 265-300. 
Sokal, R.R., and Rohlf, J.F. (1981). Biometry: the principles and practice of statistics in biological research. 2nd ed., San Francisco, W. H. Freeman and Company, p859.

Song, C, J., Thomas, W.B., and Han, Y. (2010). Value Relevance of FAS No. 157 Fair Value Hierarchy Information and the Impact of Corporate Governance Mechanisms. The Accounting Review, 85 (4), 1375-1410.

Tweedie, D. (2008). Bringing transparency to financial reporting: towards an improved accounting framework in the aftermath of the credit crisis. Financial Stability Review, Banque de France, No. 12, October, 115-120.

Venkatachalam, M. (1996). Value-relevance of banks' derivatives disclosures. Journal of Accounting and Economics, 22 (1996) 327-355.

Watts, R. L., and Zimmerman, J. L. (1978). Towards a positive theory of the determination of accounting standards. The Accounting Review, 53(1),112-134.

White, H. (1980). A heteroskedasticity-consistent covariance matrix estimator and a direct test for heteroskedasticity. Econometrica: Journal of the Econometric Society, 48(4), 817838 . 


\title{
The predictive value of bank fair values
}

\author{
Ehalaiye, D
}

2017-02-01

http://hdl.handle.net/10179/16889

22/04/2023 - Downloaded from MASSEY RESEARCH ONLINE 